\title{
Two new catfish species of typically Amazonian lineages in the Upper Rio Paraguay (Aspredinidae: Hoplomyzontinae and Trichomycteridae: Vandelliinae), with a biogeographic discussion
}

\author{
Fernando Cesar Paiva Dagosta ${ }^{1} \&$ Mário de Pinna² \\ 1 Universidade Federal da Grande Dourados (UFGD), Faculdade de Ciências Biológicas e Ambientais (FCBA). Dourados, MS, Brasil. \\ ORCID: http://orcid.org/0000-0001-7163-296X.E-mail: ferdagosta@gmail.com (corresponding author) \\ 2 Universidade de São Paulo (USP), Museu de Zoologia (MZUSP). São Paulo, SP, Brasil. \\ ORCID: http://orcid.org/0000-0003-1711-4816. E-mail: pinna@ib.usp.br
}

\begin{abstract}
Two new species of particular biogeographic significance are described from the upper rio Paraguay basin, one of the genus Paracanthopoma (Trichomycteridae, Vandelliinae) and the other of the genus Ernstichthys (Aspredinidae, Hoplomyzontinae). The two species occur sympatrically in the Rio Taquarizinho, tributary of the Rio Taquari, in the upper Paraguay system. Paracanthopoma saci is distinguished from its only congener, P. parva, by a spatulate caudal peduncle; a minuscule premaxillary dentition (reduced to three delicate teeth); the supraorbital latero-sensory canals opening as two separate 56 pores; the caudal fin slightly convex or truncate with round edges; the skull roof entirely open, unossified; the origins of dorsal and anal fins approximately at same vertical; and the pelvic fin with three rays. Ernstichthys taquari is diagnosed among congeners by the narrow bony shields on dorsal and ventral series, not overlapping or contacting each other; by the presence of seven or eight serrations on the posterior margin of the pectoral spine; and by the pectoral-fin spine only slightly larger than subsequent soft rays. Both Paracanthopoma and Ernstichthys were previously unknown outside of the Greater Amazonian river systems (Amazon, Orinoco, Essequibo and smaller surrounding drainages). Their presence restricted to the Rio Taquari is unexpected and suggests a peculiar biogeographical history. Ancestral geographic distributions were reconstructed using S-DIVA and BBM methods in RASP. A majority of resulting hypotheses support that the two species reached the Paraguay from the Amazon. The alternative explanation accounts for their presence in the Paraguay by vicariant events. In no case, their presence in the Paraguay is an ancestral distribution with subsequent Amazonian dispersal. Though unusual, this pattern is also seen in a few other fish taxa, showing that the Rio Taquari is biogeographically hybrid, combining elements from both the Paraguay and Amazon drainages.
\end{abstract}

Keywords. Systematics; Ichthyology; Biogeography; Taxonomy; Candiru; Siluriformes; Paracanthopoma; Ernstichthys.

\section{INTRODUCTION}

Historical biogeography, like most historical sciences, is a discipline that studies the past and therefore is not optimized for formulating predictions about the future (Morrone, 2009). On the other hand, historical biogeography is efficient in making retrodictions, i.e., to "predict" past events (Morrone, 1997, 2009). Of course, its predictions apply to not-yet-known results of past events. With progress in knowledge about phylogenetic relationships and distribution of Neotropical fishes, it becomes increasingly clear how geomorphological past events shaped ichthyological diversity (Albert \& Reis, 2011; Dagosta \& de Pinna,
2018; Albert et al., 2020). Because fishes have extremely limited dispersal abilities across land, the ichthyofaunal composition of a basin is an imprint of its history with other basins. However, such historical portrait is both complex and imperfect. Complex due to its temporally mixed context and imperfect because biological events such as dispersal, hybridization and extinctions tend to be blurred with time. Temporal mixing results from overlapping geomorphological processes that cause hydrological mixing between neighboring basins (i.e., connection, diversion, sector capture, etc.). Consequently, basins present a mosaic of fish assemblages composed of elements from different geographic origins recruited across dif- 
ferent times and events (Lima \& Ribeiro, 2011; Dagosta et al., 2014; Dagosta \& de Pinna, 2017).

Herein we discuss the evidence and underlying causes for two new siluriforms which are particularly eloquent testimonies of Amazonian affinities of the upper rio Taquari, rio Paraguay basin. The first one is a parasitic catfish of the genus Paracanthopoma, of subfamily Vandelliinae, family Trichomycteridae. The second one is an Ernstichthys, of subfamily Hoplomyzontinae, family Aspredinidae. Both taxa belong to previously exclusive-Amazonian-core lineages (Paracanthopoma and Hoplomyzontinae, respectively) and were collected sympatrically and syntopically in the Rio Taquari.

The Vandelliinae includes the only exclusively hematophagous gnathostomes besides vampire bats. Their ever-lasting popular fame stems from their occasional and accidental penetration of natural openings of the human body (Spotte, 2002). Vandelliines feed exclusively on blood as adults, a behavior that is general for all species in the group. Normally they enter the gill cavity of prey fishes, lacerate a blood vessel, gorge on blood and leave, but variant strategies are known to exist across the taxonomic diversity of the group, although as yet poorly understood (Kelley \& Atz, 1964; Zuanon \& Sazima, 2004). The Vandelliinae comprises four genera: Paracanthopoma, Paravandellia, Plectrochilus, and Vandellia (a fifth genus with four new species is currently under description by the authors). The subfamily as a whole occurs in the Amazon, Orinoco, Essequibo, Magdalena, and ParanaParaguay, but its center of diversity is by far the Amazon, where all genera and a majority of species are found. Actually, as yet only two species of Vandelliinae are known to occur outside the Amazon-Orinoco-Essequibo realm, both of Paravandellia: P. oxyptera Miranda-Ribeiro, 1912 from La Plata and Amazon and P. phaneronema (Miles, 1943) from the Rio Magdalena basin.

Paracanthopoma currently comprises a single described species, P. parva Giltay, 1935, but new species in the process of description will increase that diversity by an order of magnitude (de Pinna \& Dagosta, in prep.). The genus is easily diagnosable by several unique morphological characteristics, among which the presence of a free fold of integument across the isthmus, a trait whose significance is recognized since the original description of the taxon and which remains valid today. Species of Paracanthopoma occur throughout lowlands and uplands of the Amazon, Orinoco, and Essequibo, but were so far absent outside of those basins. Given the amount of ichthyological surveying so far conducted in the Paraná-Paraguay, São Francisco, and Coastal Brazilian drainages, combined with the conspicuousness of Paracanthopoma species and their abundance in the Amazon, it seemed highly unlikely that the genus occurred outside the broad Amazonian realm. Still, small pockets of hidden diversity exist and herein we report on a new species of Paracanthopoma which unexpectedly surfaced in the Rio Taquari, upper Paraguay. It seems to be a narrowly endemic form, and is the first of its genus from outside the Amazon-Orinoco realm. This is the first new species of Vandelliinae described since 1943.
The Hoplomyzontinae is the rarest and least known aspredinid subfamily. The first described member of the group was Hoplomyzon atrizona Myers, 1942 and recognition of a suprageneric taxon came with FernándezYépez (Fernández-Yépez, 1953). Additional diversity has been slow in forthcoming and collections of hoplomyzontines are still rare. However, there is evidence that their abundance and ecological relevance may be far larger than current sparse museum collections seem to suggest (Taphorn \& Marrero, 1990). The subfamily contains Dupouyichthys Schultz, 1944 (1 sp.), Ernstichthys Fernández-Yépez, 1953 (3 spp.), Hoplomyzon Myers, 1942 (4 spp.), and Micromyzon Friel \& Lundberg, 1996 (2 spp.) and all its species are small-sized. The morphology of hoplomyzontines is aberrant, with several adaptations unique among siluriforms, including a complex body armor composed of shield- and plate-like modifications derived from different skeletal elements. Despite being such an obvious object of interest for morphological investigation, the anatomy of Hoplomyzontinae remained poorly-known until recently, with fragmentary information scattered in various publications. This situation began to change with Carvalho et al. (2016) and Carvalho et al. (2017) which offered an unprecedented picture of the osteology of Micromyzon orinoco and Hoplomyzon cardosoi. Hoplomyzontine taxonomy is relatively tidy, as might be expected for such a small group, but some generic limits are based on rather limited character evidence. Phylogenetically, while monophyly of hoplomyzontines is unchallenged and extremely well-supported (Friel, 1994; Cardoso, 2008; Carvalho et al., 2018), their relationships within Aspredinidae are still controversial. Some studies support the genus Xyliphius as sister group to Hoplomyzontinae (Friel, 1994) while some others place the subfamily as sister group to different subsets of aspredinids (Cardoso, 2008; Carvalho et al., 2018). Proposals of relationships within hoplomyzontines also diverge, with some hypotheses placing Hoplomyzon as sister group to the rest of the subfamily, with Micromyzon as sister to Dupouyichthys plus Ernstichthys (Friel \& Lundberg, 1996) and others with the positions of Hoplomyzon and Micromyzon switched relative to that one (Cardoso, 2008).

Geographically, hoplomyzontines are mostly restricted to Andean piedmonts in the western Amazon, western Orinoco, Maracaibo and Magdalena drainages in a distribution pattern called Cis-Andean Foothills (Dagosta \& de Pinna, 2019). Exceptions to that pattern are the two lowland Amazonian and Orinocoan species of the genus Micromyzon (Friel \& Lundberg, 1996; Carvalho et al., 2016) and a few isolated and taxonomically yet poorly understood records of Ernstichthys and "Dupouyichthys" in lower portions of Rio Madeira (Ohara \& Zuanon, 2013) and of Ernstichthys in the Rio Pilcomayo in Bolivia and upper Rio Tocantins (Jarduli et al., 2014; Tiago Carvalho, pers. comm.). In any case, the geographic distribution of the Hoplomyzontinae known to date seemed to be solidly restricted to the northern basins of South America. The discovery of a new hoplomyzontine species in the rio Taquari was therefore as surprising as the finding of its 
co-occurring Paracanthopoma. Given such unusual circumstances, it is fitting to describe them together in this publication, as taxonomic supplements to a discussion on the biogeographical implications of the Amazonian components of the upper Rio Paraguay.

\section{MATERIAL AND METHODS}

Specimens were collected under the collecting permit \# 60634/1 issued to F.C.P.D. by the Instituto Chico Mendes de Conservação da Biodiversidade (ICMBio) of the Ministry of Environment. Fishes were anesthetized through Eugenol solution, according to the protocol of Lucena et al. (2013). Standard length (SL) is given in millimeters. In morphometric data, subunits of the body are expressed as percentages of SL and subunits of head as percentages of head length ( $\mathrm{HL})$. Measurements were point-to-point, taken with digital calipers to the nearest $0.1 \mathrm{~mm}$, except for subunits of the head in Paracanthopoma, which were obtained with an ocular micrometer and therefore as projections. Definitions of measurements and meristics for Paracanhopoma follow Reis \& de Pinna (2019). Odontodes were counted on cleared and stained (c\&s) preparations, and included odontodes that are attached to bone, or replacement odontodes in the process of filling in for an already detached odontode, or an obviously empty socket which happens to have lost both its occupant and replacement odontode. Claw-like teeth were counted as those actually attached to the premaxilla, with replacement teeth and sockets mentioned separately in the description. The integument fold acros the isthmus in Paracanthopoma, called a branchiostegal or branchial membrane by previous authors, is here called a branchiostegal velum, to reflect its particular structure unique to the genus (see Discussion below). Definitions of measurements for Ernstichthys follow Carvalho et al. (2015). Vertebral counts include all preural vertebrae, including five in the Weberian apparatus for hoplomyzontines, but not for Paracanthopoma, plus the terminal complex PU1+U1 counted as one. The differentiated U2 of Ernstichthys (as in other Aspredinidae) was not included in counts (de Pinna \& Ng, 2004). In the description, the frequency of each count is provided in parentheses after the respective count, with the count of the holotype indicated by an asterisk. Cleared and counterstained specimens for comparative material were prepared according to Taylor \& Van Dyke (1985). High-resolution CT scan figures are available at the online repository Harvard Dataverse https://dataverse.harvard.edu/dataverse/harvard, available at http://doi.org/10.7910/DVN/XCXEM8 (Dagosta, 2021). Radiographs were taken with a Faxitron digital x-ray model. Number of serrations on the posterior margin of the pectoral spine from other species of Ernstichthys were taken from the literature (e.g., Ohara \& Zuanon, 2013; Stewart, 1985) and from material examined at MZUSP. Osteological observations in the new Ernstichthys were done by computerized tomography of the holotype only. Osteological terminology follows de
Pinna (1996), with the lacrimal being shorthand for the compound lacrimal+antorbital (de Pinna et al., 2020). So called "bony plates" in hoplomyzontines are anatomically heterogeneous. The lateral series is formed from expanded lateral-line ossicles, and are thus independent dermal bones. Remaining plate-like structures in the dorsal and ventral series are part of internal skeletal structures that emerge at the surface, thus not really independent dermal plates. The term plates is thus herein reserved for elements of the lateral series, while the dorsal and ventral series are called shields. Plates independent of both internal structures and lateral-line canals, such as in some loricarioids (Callichthyidae, Scoloplacidae, Loricariidae) are absent in hoplomyzontines. Lists of types and comparative material include catalog numbers followed by the number of specimens in alcohol, their SL range, number of $c \& s$ specimens and respective SL range. Institutional abbreviations follow Sabaj (2020).

\section{Biogeographic analyses}

Ancestral geographic distributions were reconstructed using statistical dispersal-vicariance analysis S-DIVA (Yu et al., 2010) and BBM (Ali et al., 2012) in RASP (Yu et al., 2015). Those models are the only ones available for ancestral reconstruction from trees without branch lengths in RASP. Trees were built in Mesquite (Maddison \& Maddison, 2019) and exported in Nexus format to RASP. In the case of Trichomycteridae, the MTSVG clade from Ochoa et al. (2017) was supplemented

Table 1. Distribution of taxa coded in S-DIVA. Biogeographical regions: $A=$ Amazon-core; $B=$ São Francisco and Eastern Coastal drainages; $C=$ ParanáParaguay; $D=$ Trans-Andean.

\begin{tabular}{|c|c|c|c|}
\hline Trichomycteridae & & Aspredinidae & \\
\hline Listrura & B & Pseudobunocephalus & $A C$ \\
\hline Microcambeva & B & Acanthobunocephalus & $A$ \\
\hline Potamoglanis & $A C$ & Hoplomyzon & $A D$ \\
\hline Stauroglanis & $A$ & Micromyzon & $A$ \\
\hline Sarcoglanis & A & Ernstichthys & $A C$ \\
\hline Typhlobelus & $A$ & Bunocephalus chamaizelus & $A$ \\
\hline Pygidianops & $A$ & Aspredinichthys & $A$ \\
\hline Tridens & A & Aspredo & A \\
\hline Tridensimilis & $A$ & Platystacus & $A$ \\
\hline Tridentopsis & $A C$ & Xyliphius & $A C D$ \\
\hline Stegophilus & $A B$ & Pterobunocephalus & $A C$ \\
\hline Haemomaster & $A$ & Amaralia & $A C$ \\
\hline Ochmacanthus & $A C$ & Bunocephalus & $A B C D$ \\
\hline Homodiaetus & $B$ & Amaralia & $A C$ \\
\hline Megalocentor & A & Dupouyichthys & $D$ \\
\hline Henonemus & $A$ & & \\
\hline Pareiodon & A & & \\
\hline Acanthopoma & $A$ & & \\
\hline Pseudostegophilus & $A C$ & & \\
\hline Paracanthopoma saci & $C$ & & \\
\hline Paracanthopoma parva & $A$ & & \\
\hline Paravandellia oxyptera & $A C$ & & \\
\hline Paravandellia phaneronema & $D$ & & \\
\hline Vandellia & $A$ & & \\
\hline
\end{tabular}


with the addition of two valid species of Paravandellia. Morphological evidence supports the genus as the sister group to Paracanthopoma (DoNascimiento, 2015), and its inclusion in the analysis is biogeographically relevant. For Aspredinidae, the tree used was from Carvalho et al. (2018), with the addition of Dupouyichthys, sister genus to Ernstichthys (Friel, 1994; Friel \& Lundberg, 1996) and therefore important for a biogeographic understanding of the group. Coding of terminal distributions was at the genus level (Table 1), except in case of Paravandellia and Paracanthopoma where relationships at species level were necessary for biogeographic accuracy. Analyses in S-DIVA and BBM were conducted with default settings (comparative analyses conducted with more aggressive parameters yielded the same general results). Four biogeographical regions were defined: $A=$ Amazoncore; B = São Francisco and Eastern Coastal drainages; $C=$ Paraná-Paraguay; $D=$ Trans-Andean. The number of maximum ancestral areas was set to the maximum, limited by the number of regions previously determined (4 areas each in Trichomycteridae and Aspredinidae).

\section{RESULTS}

\section{Paracanthopoma saci sp. nov.} http://zoobank.org/6536E8CD-A751-4CEF-AD74-FAA3669F99D6 (Figs. 1-2)

Holotype: MZUSP 125624, $19.1 \mathrm{~mm} \mathrm{SL}$, Brazil, Mato Grosso do Sul, Alcinópolis, Rio Taquarizinho (tributary to Rio Taquari, Rio Paraguay drainage) (18 $12^{\prime} 14.8^{\prime \prime} \mathrm{S}$, 53³4'11.3"W), elev. 363 m, col. F. Dagosta, A. Ferreira, R. Zanon, 18 Sep 2019.

Paratypes: MZUSP 125626, 13 ex (2 c\&s), 14.5-21.8 $\mathrm{mm} \mathrm{SL}$, collected with holotype. MZUSP 125622, 2 ex, 19.5-19.9 mm SL, same locality and col- lectors as holotype, 17 Sep 2019. MZUSP 115585, 1 ex, $19.3 \mathrm{~mm} \mathrm{SL}$, Brazil, Mato Grosso do Sul, Alcinópolis, stream tributary to Rio Taquari (Rio Paraguay drainage) at dirt road between Alcinópolis and road MS-217 $\left(18^{\circ} 12^{\prime} 16.5^{\prime \prime} \mathrm{S}, 53^{\circ} 34^{\prime} 13.5^{\prime \prime} \mathrm{W}\right)$, col. O.T. Oyakawa, P. Camelier, M. Marinho, F. Dagosta, 26 Aug 2013. MNRJ 53559, 2 ex, 14.6-16,8 mm SL, from MZUSP 125626.

\section{Diagnosis}

Distinguished from the only other species of Paracanthopoma, P. parva, by: 1) short and anteriorly-displaced opercular patch of odontodes, which leaves a large posterior free area of integument continuous with the rest of the head integument around it (as a consequence of that morphology, in dorsal view the posterior tips of the opercular odontodes do not reach the base of the pectoral fin); 2) pelvic fin with three rays (vs. five); 3) opercle lacking an ascending process (vs. ascending process present); 4) caudal peduncle spatulate by hypertrophied series of 22-29 (upper) and 20-29 (lower) procurrent caudal-fin rays (vs. caudal peduncle narrow, with 15 to 19 upper and 14 to 18 lower rays); 5) median premaxillary dentition feeble, with three delicate teeth (vs. median premaxillary dentition robust, with nine large strong teeth); 6) supraorbital canals opening as two separate 56 pores (vs. canals fused at midline and opening as single median s6 pore); 7) caudal fin slightly convex or truncate, with round edges (Fig. 2; in Fig. 1 the apparent emarginated margin is a preservation artifact) (vs. bilobed or emarginate, concave); 8) supraoccipital lacking anterior median process (vs. supraoccipital with produced anterior process); 9) origins of dorsal and anal fins approximately at same vertical (vs. origin of dorsal fin clearly anterior to vertical through origin of anal fin). The three former characters also distinguish $P$. saci from all undescribed species of the genus known to the authors at this time.

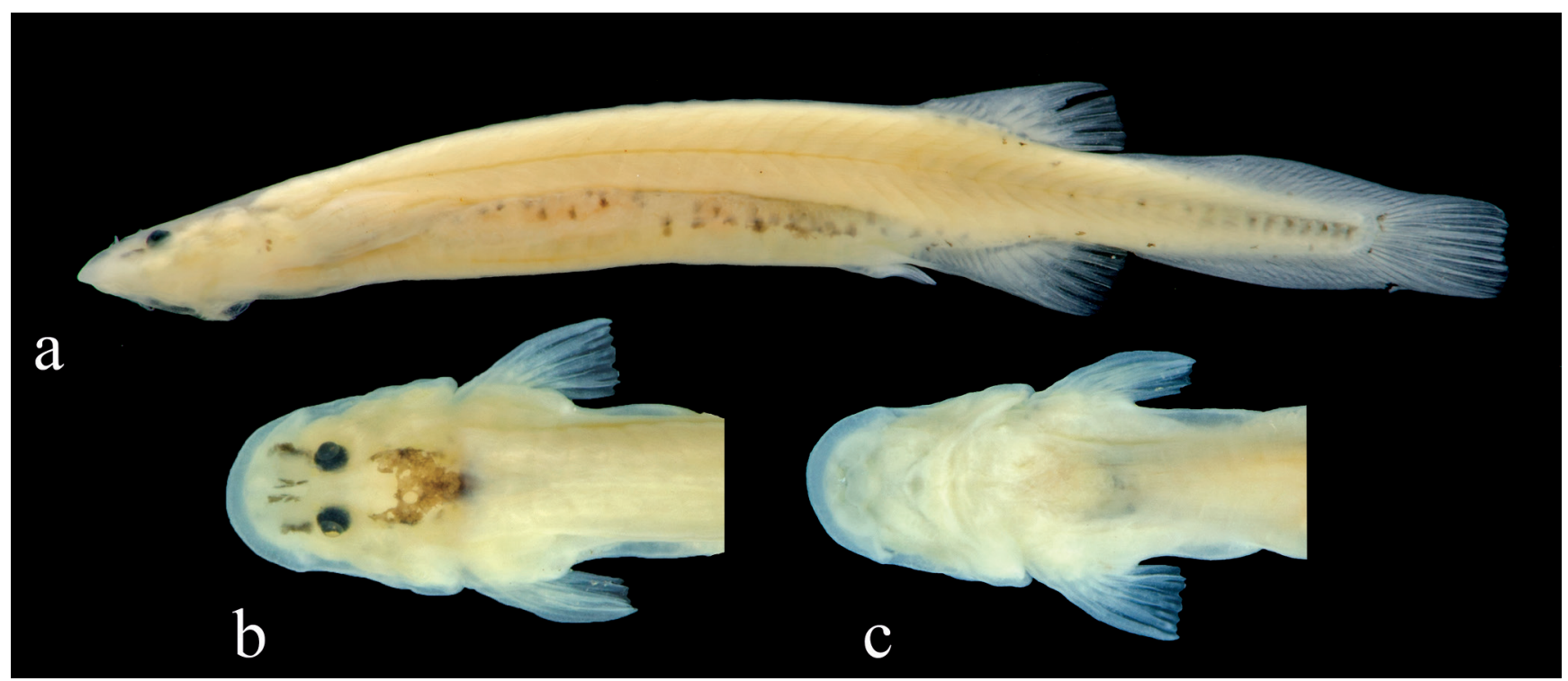

Figure 1. Paracanthopoma saci, MZUSP 125624, holotype, 19.1 mm SL. Brazil, Mato Grosso do Sul, Alcinópolis, Rio Taquarizinho. (a) Lateral view, (b) Dorsal view of head, (c) Ventral view of head. Photos by V. Reis. 
Table 2. Morphometric data of Paracanthopoma saci. Ranges, mean and SD (standard deviation) include holotype. Head subunits were obtained with an ocular micrometer and therefore as projections.

\begin{tabular}{lcccccc}
\hline & $\mathbf{n}$ & holotype & min & max & mean & SD \\
\hline Standard length $(\mathrm{mm})$ & 8 & 19.1 & 15.4 & 21.1 & 18.1 & 1.8 \\
Total length & 8 & 112.5 & 17.3 & 23.5 & 20.3 & 2.0 \\
Body depth & 8 & 13.1 & 11.7 & 15.7 & 13.9 & 1.5 \\
Caudal-peduncle length & 8 & 25.1 & 24.0 & 26.6 & 25.0 & 1.0 \\
Caudal-peduncle depth & 8 & 9.9 & 8.9 & 11.3 & 9.8 & 0.8 \\
Predorsal length & 8 & 68.6 & 66.5 & 69.2 & 68.2 & 0.9 \\
Preanal length & 8 & 67.5 & 65.5 & 68.8 & 67.2 & 1.1 \\
Prepelvic length & 8 & 60.2 & 56.0 & 61.1 & 59.4 & 1.5 \\
Dorsal-fin base length & 8 & 9.4 & 6.8 & 10.3 & 8.6 & 1.2 \\
Anal-fin base length & 8 & 11 & 7.6 & 11.0 & 9.0 & 1.0 \\
Pectoral-fin length & 8 & 11.5 & 9.7 & 12.3 & 10.8 & 0.8 \\
Head length (mm) & 8 & 15.7 & 15.1 & 16.1 & 15.7 & 0.4 \\
Head width & 8 & 83.6 & 83.6 & 100.0 & 89.2 & 5.1 \\
Head depth & 8 & 41.8 & 41.8 & 54.6 & 50.3 & 4.0 \\
Interorbital & 8 & 13.6 & 12.6 & 15.5 & 13.8 & 1.0 \\
Eye diameter & 8 & 12.7 & 11.3 & 13.6 & 12.8 & 0.7 \\
Snout length & 8 & 36.4 & 35.8 & 39.8 & 37.2 & 1.4 \\
Mouth width & 8 & 23.6 & 14.6 & 28.6 & 24.6 & 4.3 \\
Anterior internarial width & 8 & 15.5 & 14.6 & 21.8 & 17.2 & 2.4 \\
Posterior internarial width & 8 & 10.9 & 9.7 & 13.6 & 11.0 & 1.2 \\
\hline
\end{tabular}

\section{Description}

Morphometric data provided in Table 2. Body elongate. Cross-section of body as broad as deep at pectoral-fin insertion and increasingly compressed posterior to that point, tapering to caudal fin. Dorsal profile of body in broad gentle arc, nearly straight, from head to origin of dorsal fin (Figs. 1-2). Dorsal midline with transparent fin fold anterior to dorsal fin. Dorsal and ventral profiles of caudal peduncle straight immediately posterior to ends of dorsal and anal fins, then expanded by dorsal and ventral procurrent caudal-fin rays resulting in symmetrically spatulate caudal peduncle. Ventral profile of body nearly straight until pelvic-fin origin, but greatly distended in some specimens due to gut contents. Myotomes and longitudinal skeletogenous septum clearly visible through thin integument along whole body. Axillary gland large, elongate, positioned dorsal to pectoral-fin base and extending posteriorly approximately to midlength of adpressed pectoral fin, its large round or oval pore located at its posterior terminus. Some specimens preserved with large amount coagulated secretion still attached to pore.
Dorsal profile of head continuous with that of dorsum. Head longer than broad, snout very broad, semicircular with a continuous round anterior margin. Head muscles not entering skull roof. Head depressed (head depth approximately $50 \%$ of head width) with dorsal profile mostly continuous from nape to tip of snout. Ventral profile of head straight, flattened, though externally irregular due to integument folds. Eye size slightly less than one-third of snout length, without free orbital rim, located dorsally on head and directed dorsolaterally. Integument over eyes thin and transparent. Center of eyes located slightly anterior to middle of $\mathrm{HL}$, interorbital width equal to, or slightly larger than, longitudinal diameter of eye. Eye lens unconstricted by iris, entirely exposed on external aspect of eye. Anterior nostril small, surrounded by short tubule of integument produced posteriorly into small and pointed flap. Anterior internarial width slightly narrower than interorbital. Posterior nares slightly larger than anterior ones, oval (longer than broad) in shape, located close to anteromesial margin of eyes. Center of posterior nares slightly anterior to transverse line through anterior margin of eyes. Posterior internarial width slender than interorbital and approximately twice as wide as anteroposterior length of nostril.

Opercular patch of odontodes tiny, dorsolaterally located on head, on dorsal half of head depth in lateral view, anterodorsally to pectoral-fin base. Opercular odontodes six, disposed in two irregular rows. Odontodes with distal portions curved medially. Opercular fold of integument vestigial or absent, instead continuous with large well-delimited roundish area of thickened integument resembling a vastly hypertrophied opercular fold. Interopercular patch of odontodes miniscule, nearly invisible on surface of head, located ventrolaterally on head, horizontally aligned with origin of pectoral fin. Interopercular odontodes four. Interopercular patch of odontodes closer to opercular patch than to eye. Interopercular flap of integument absent or vestigial.

Mouth ventral and small, strongly flattened ventrally, delineated anteriorly and laterally by vast crescent-shaped upper lip and posteriorly by small lower lip. Each premaxilla with a single claw-like tooth attached to its distal tip, and one additional tooth socket with partly-formed tooth in parallel. Claw-like tooth deeply hidden in labial tissue and difficult to expose in preserved specimens without damaging soft tissue. Conical teeth absent on premaxilla. Upper lip very broad but poorly-differentiated, continuous with ventral surface of snout. Median

Figure 2. Live coloration of Paracanthopoma saci. Lateral view of MZUSP 125622, 19.9 mm SL. 
premaxilla miniscule, with three closely-set tiny teeth. Dermal pad of median premaxilla semicircular. Lower jaw narrow, its anterior profile M-shaped and composed mostly of produced dentary lobes, continuous with mental region posteriorly. Jaw cleft short, strongly directed posteriorly, but curved laterally at posterior end. Dentary diastema as deep median concavity between dentary lobes. Dentary teeth four on each side, large but difficult to visualize in alcoholic specimens, concentrated at mesial end of dentary and directed anteromesially, arranged in two ventral and two dorsal ones, not aligned. Dentary teeth long, their axis anteriorly-directed at base, but curved dorsally or dorsolaterally at distal half. Median tooth of ventral row longer than others.

Branchiostegal membrane continuous posteriorly with large, continuous, posteriorly concave, free branchiostegal velum across whole of ishtmus region. Dorsal portion of branchiostegal velum reaching and slightly overlapping anterior margin of pectoral-fin base. Branchial opening small, located anteriorly to pectoral-fin base, approximately equal to space between opercular and interopercular patches of odontodes. Maxillary barbel ranging from extremely short to vestigial, extending maximally for one-third distance between its base and base of interopercular patch of odontodes. Posterior point of its base slightly anterior to vertical through anterior margin of eye in lateral view. Rictal barbel vestigial, reduced to small knob mesially to base of maxillary one, absent in some specimens. Nasal barbel vestigially represented by posterior elongated portion of fold around anterior naris described above.

Lateral line short, approximately half of pectoral-fin length, and straight, extending alongside dorsal margin of anterior portion of axillary gland. Terminal lateral-line pore immediately dorsal to axillary gland opening. Short secondary branch splitting off ventrally from proximal portion of main canal, with corresponding pore opening anteriorly to midlength of main canal. Single lateral-line tubule poorly calcified, extending over part of main canal immediately posterior to bifurcation.

Pectoral fin small, approximately $60 \%$ of $\mathrm{HL}$, with $\mathrm{i}+4$ rays in all specimens (except $\mathrm{i}+3$ in one side of one specimen). Pectoral-fin morphology with pronounced variation, with most specimens ( $\mathrm{n}=9$, including holotype) having triangular pointed shape with first ray slightly longer than others. Some specimens $(n=5)$ with all rays equally long, resulting in truncate fin margin. Two exceptional specimens in MZUSP 125626 (14.5 and $15.0 \mathrm{~mm} \mathrm{SL}$ ) with hypertrophied first pectoral-fin ray forming long filament. First ray corresponding to $36 \% \mathrm{SL}$ in smaller specimen and $26 \% \mathrm{SL}$ in larger specimen, with filamentous portion approximately 2 and 1.5 times length of rest of fin, respectively (see Remarks below). Pelvic fins minute, closely set together at base, with i+2 rays (with all three rays unbranched in small specimens; one specimen with vestigial additional ray posteriorly). Pelvic splint present in single of three c\&s specimens. Origin of pelvic fin close to origin of anal fin, well anterior to vertical through origin of dorsal fin, extending posteriorly well beyond anus and urogenital papilla and slightly beyond origin of anal fin. Posterior margin of pelvic fin gently convex. Dorsal fin elongate, roughly triangular with roundish edge and gently convex, sinusoidal or straight distal margin. Dorsal-fin rays $\mathrm{v}-\mathrm{viii}{ }^{*}+\mathrm{I}^{*}-\mathrm{II}+5-6^{*}$. Anal fin similar in shape to dorsal fin, with v-ix $\left(\right.$ viii $\left.^{*}\right)+\mathrm{I}+5$ rays. Origin of anal fin at or slightly posterior to vertical through origin of dorsal-fin. Caudal fin roughly rectangular in preserved position.. Margin of caudal fin truncate with round edges and gently convex margin (in Fig. 1 the apparent emarginated margin is an artifact of the preservation position of middle rays). Principal caudal-fin rays $5+5^{*}$ or $4+5$. Procurrent caudal-fin rays $22-29$ dorsally and 20-29 ventrally.

Vertebrae (exclusive of Weberian complex) $40(n=2)$, $41(n=3), 42^{*}(n=4), 43(n=3)$. First dorsal-fin pterygiophore positioned subsequent to neural spine of vertebra $22(n=3)$. First anal-fin pterygiophore positioned subsequent to hemal spine of vertebra $22(n=1)$ or $23(n=2)$. Dorsal- and anal-fin pterygiophores six, poorly calcified or entirely cartilaginous, clearly visible only in c\&s preparations. Branchiostegal rays three. Ribs one pair.

\section{Pigmentation in alcohol}

General aspect of fish almost entirely white. Postorbital part of skull roof with extensive dark field formed by brain pigment seen by transparency, its anterior margin strongly concave, in continuous arc or angulate, immediately posterior to eyes. Well-defined elongate dark field extending anterior to eye, along lateral margin of olfactory capsule. In some specimens, mesial margin of olfactory capsule also with some dark pigment, but much weaker than lateral one. Dark pigment on body restricted to uniform web-like or dotted covering on dorsal part of abdominal wall and few isolated small spots along base of dorsal fin and, rarely, of anal and caudal fins and muscular margins of caudal peduncle. Posterior portion of vertebral column with internal dark pigment on each individual vertebra, forming series of spots visible externally by transparency along caudal peduncle (more evident in life). All fins hyaline.

\section{Pigmentation in life}

Based on Fig. 2. General body color translucent yellowish. Neural canal darkly pigmented along entire vertebral column, forming continuous thin dark line along whole body. Hemal canal forming reddish line ventrally along vertebral column. Limits between vertebrae from middle of abdomen to base of caudal skeleton outlined in dark by internal pigment. Branchial region pink and cardiac region intense red due to blood seen by transparency. Abdomen yellow anteriorly and abruptly dark posteriorly due to ingested blood. Dorsal portion of abdomen with iridescent golden speckles, concentrated on its anterior and posterior limits. Eggs and fatty globules faintly visible along dorsal part of abdomen. Superficial integumentary dark pigmentation as described in preserved specimens. 


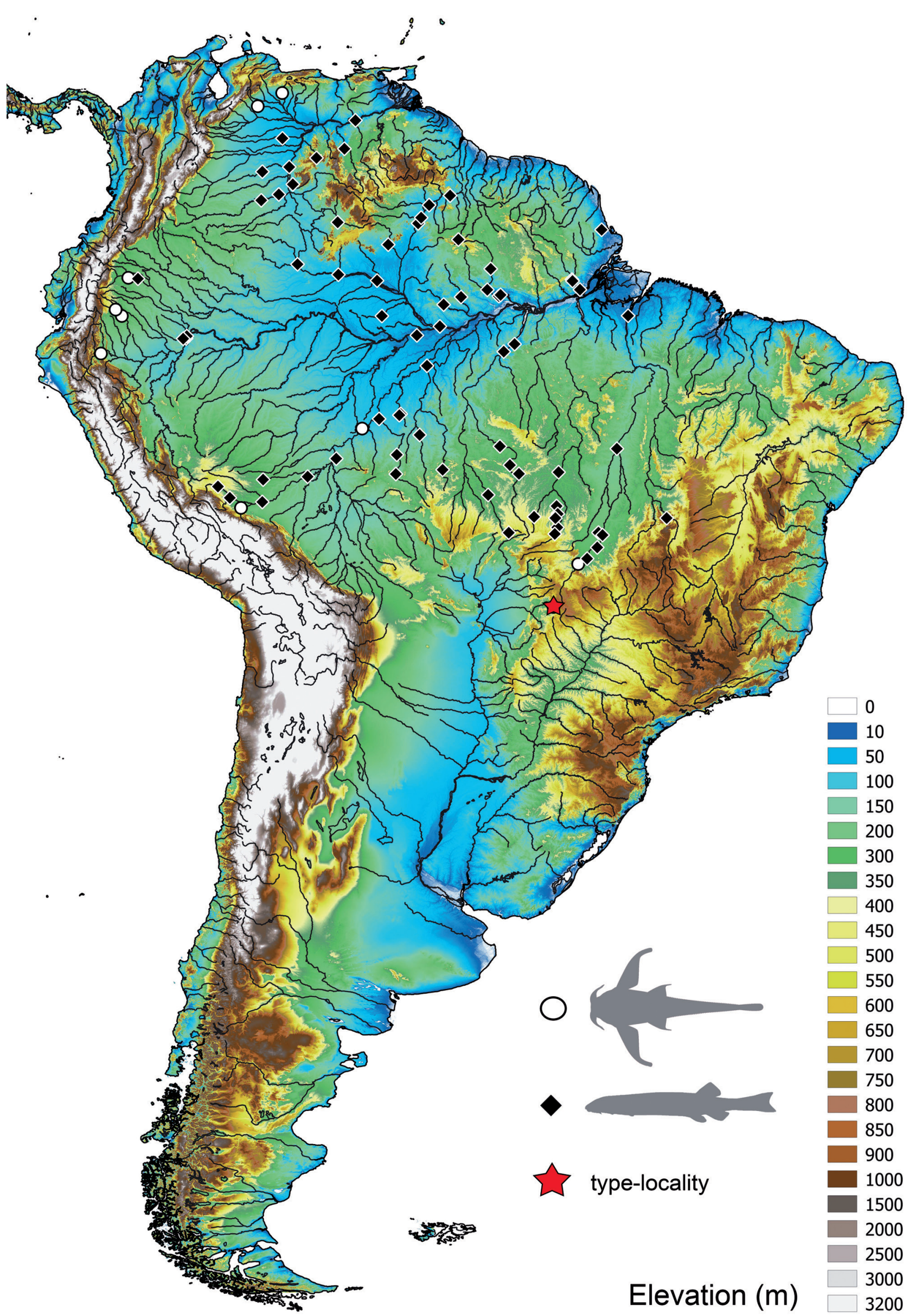

Figure 3. Distribution map of Ernstichthys spp. (open dots) and Paracanthopoma spp. (black diamonds). Red star indicates type-locality of Ernstichthys taquari and Paracanthopoma saci. 


\section{Ecology}

The Rio Taquarizinho is ca. $15 \mathrm{~m}$ wide at the collection locality. Water is clear, slightly milky and with moderate current. Specimens were collected by seining on sand banks in the middle of the river, especially in sectors shaded by riparian vegetation. There was no aquatic vegetation and depth of collection ranged from 30 to $150 \mathrm{~cm}$. Paracanthopoma saci is sympatric with Paravandellia oxyptera (MZUSP 125623, 125625) with both relatively abundant at the type locality. The two species are psammophilic, but with different microhabitat preferences. Paracanthopoma saci favors fine sand, while $P$. oxytera prefers sectors with coarser granulation. Once the subtleties of their preferences are understood, it is possible to target one or the other species for collection with reasonable accuracy. Segregation is not complete however, and occasionally they were captured together in the same net (F. Dagosta, pers. obs.). The abdomen is distended with blood in several specimens. Some female specimens (two each in MZUSP 125622 and 125626) have large eggs, approximately eye-sized or slightly larger, visible by transparency (Fig. 2). Distribution of eggs extending along ventral margin of hypaxial musculature from shortly posterior to end of pectoral fin to nearly end of abdominal cavity, with approximately 20 eggs visible in lateral layer of each side (certainly more in inner portions of gonad).

\section{Etymology}

The name honors the SACl expedition (South American Characiform Inventory, under direction of $\mathrm{N}$. Menezes) which collected the first known specimen of this species. Appropriately, Saci is also the name of a Brazilian rural folklore supernatural entity (complete name: saci-pererê), personified as a nocturnal, onelegged, hopping, red-capped, pipe-smoking black boy, transmutable into dust devils and fond of mischievous deeds aimed at terrorizing or annoying people and other animals.

\section{Remarks}

Paracanthopoma saci is the only species of Paracanthopoma outside of the core Amazonian drainages (see Geographical Distribution above) and only the second species of Vandelliinae from the entire ParanáParaguay basin (the other being Paravandellia oxyptera). In addition to the new species of Ernstichthys reported below, other fish collected with $P$. saci were all typical members of the Paraná-Paraguay fish fauna, including some endemics (e.g., Cyphocharax gillii, Steindachnerina brevipinna, Creagrutus meridionalis, Brachychalcinus retrospina). As a member of Paracanthopoma, $P$. saci is a genus-level addition to the general composition of the Paraguay basin.

Two paratypes of Paracanthopoma saci have extraordinarily elongated first pectoral-fin rays (part of MZUSP 125626, see Description above). This is the most extreme case of filamentous pectoral-fin ray known in Trichomycteridae (where the filament is never longer than the length of the rest of the fin). No other specimens of the species show any sign of fin elongation. The significance of this trait is difficult to interpret with the information available. The two filamentous specimens are identical in all other relevant characteristics to other putative conspecifics, there being thus no reason to suspect that they might represent a different taxon. At 14.5 and $15.0 \mathrm{~mm} \mathrm{SL}$, those two specimens are among the smallest known of $P$. saci. Sexual dimorphism in pectoral-fin size and structure exists in all species of Paravandellia and some undescribed species of Paracanthopoma, with mature males having a stouter and larger pectoral fin, a differential particularly pronounced in the first ray (MdP, pers. obs.). No such association is evident in P. saci. An alternative hypothesis of juvenile specialization is possible. The longest filament, corresponding to $36 \% \mathrm{SL}$, is seen in the smallest specimen. In the second specimen, only slightly larger, the filament is reduced to $26 \%$ SL. Other specimens similar in size to the latter show no sign of filament. So, if the filament is indeed a juvenile specialization, it is reduced very abruptly in the course of ontogeny (or perhaps broken off). Resolution of this question will have to await additional material and data.

The extremely reduced opercular and interopercular armatures of Paracanthopoma saci, a reduction reflected in their vestigial (opercular) or absent (interopercular) integument folds, raises questions about the functionality of that complex in the species. One specimen in MZUSP 125626 is preserved with opercular odontodes erect, a sign that the biomechanical links usually associated with the movement of the opercular patch of odontodes are still functional in the species. No such evidence exists for the still more reduced interopercular armature. Given that the latter is not only tiny in size in P. saci but also quite buried in integument, it may be reduced to a vestigial condition. Reductions of opercular and interopercular armature are recurrent in different lineages of sand-dwelling trichomycterids, such as psammophilic taxa in Glanapteryginae and Sarcoglanidinae. Despite such reductions, it is certain that $P$. saci is hematophagous like all other vandelliines, because several specimens in MZUSP 125626 have visible coagulated blood in their guts.

\section{Geographic distribution}

The species is so far known from a single locality in the Upper Rio Taquari system (Rio Paraguay drainage). It marks the southernmost limit of the genus.

\section{Conservation status}

Paracanthopoma saci is endemic to Brazil and only known from its type-locality at the upper Rio Taquari. Its area of occupancy (AOO) (B2) $4 \mathrm{~km}^{2}$ is based on this only known record. The $\mathrm{AOO}$ is likely underestimated and since its hematophagous habits may mean that its transported by host fish over distances beyond its own 
vagility limits, as reported for a congener (Zuanon \& Sazima, 2005). Although the Rio Taquari has historically been reported to carry a large sediment load, this characteristic has intensified starting in the late 1970's, with the increase of agriculture and pasture in the region (Soriano et al., 2001). It has been proposed that Quartzipsamment soils in the region are important sources of sediments that intensify siltation of the Taquari (Galdino et al., 2013), which is considered as the most serious environmental and socio-economic problem in the Pantanal (Soriano et al., 2001). Because $P$. saci is hematophagous, it is necessary to better know its natural hosts. If such hosts are migratory species, they may also be negatively impacted by siltation, thus representing a threat to the feeding resources of $P$. saci. Such a situation represents a continuing decline of habitat quality. At present, none of those factors are known in any detail and therefore we suggest the species is assessed as DD (iii) according to the International Union for Conservation of Nature (IUCN) categories and criteria (IUCN, 2020).

\section{Ernstichthys taquari sp. nov. http://zoobank.org/17ADE44D-AB3D-407A-AA08-9011EFE0F470} (Figs. 4-6)

Holotype: MZUSP 125825, 22.8 mm SL, Brazil, Mato Grosso do Sul, Alcinópolis, Rio Taquarizinho (tributary to rio Taquari, rio Paraguay drainage) (18 $12^{\prime} 14.8^{\prime \prime} \mathrm{S}$, 5334'11.3"W), elev. 363 m, col. F. Dagosta, A. Ferreira, R. Zanon, 18 Sep 2019.

Paratypes: MZUSP 125826, 2 ex, 20.2-22.7 mm SL, collected with holotype.

\section{Diagnosis}

Ernstichthys taquari differs from all congeners by: 1) the relatively narrow bilateral bony shields on dorsal and ventral series, which do not overlap or contact each other anywhere in both series (vs. adjacent shields contacting or overlapping along most or entire series; this trait also distinguishes the species from most hoplomyzontine species except those of Hoplomyzon); 2) the presence of seven or eight serrations on the posterior margin of the pectoral spine (vs. 10-18); 3) the pectoral-fin spine only slightly larger than subsequent soft rays, so that there is a gradual transition between the spine and the rest of fin (vs. spine $25 \%$ longer or more than soft rays, leaving large portion of protruding spine without corresponding fin web distally). Further distinguished from E. megistus by the presence of a well-developed rictal barbel (vs. barbel absent or reduced to bump). Further distinguished from $E$. intosus by the unbranched maxillary barbel (vs. with thread-like secondary barbels); by the lack of dentations along the anterior margin of the pectoral fin (vs. dentations present); by the presence of two pairs of stout and regularly-positioned mental barbels (Figs. 4-5; vs. over 100 thread-like and uniformly distributed barbels); by the presence of $i+4$ dorsal-fin rays (vs. $\mathrm{i}+7$ ); by the presence of $\mathrm{i}+6$ anal-fin rays (vs. viii+4); by the basipterygium entirely hidden in integument (vs. anterolateral arm of basipterygium exposed on the skin, forming rugose shield).

\section{Description}

General body aspect, shape and pigmentation in Figs. 4-5. Morphometric data in Table 3. Dorsal and ventral profiles of body and head in nearly mirror images of each other, gently convex to origins of dorsal and anal fins, respectively, then straight along to nearly end of caudal peduncle. Greatest depth of body at posterior part of head and greatest width between bases of pectoral-fin spines. Caudal peduncle depressed for most of its length, except for compressed terminus near base of caudal fin. Caudal peduncle least deep at ca. threefourths of its length. Head depressed, gently convex in dorsal and ventral profiles. Mid-dorsal cephalic region with three bony prominences disposed in line, anterior one occipital, at limit between supraoccipital and neural complex of Weberian apparatus, second one formed by posterior part of neural complex of Weberian apparatus and third one immediately anterior to dorsal fin, formed by central portion of middle nuchal plate (Fig. 6). Anterior cranial fontanel large, elongate-ovoid, with anterior portion narrower than posterior one, occupying most of body of mesethmoid and anterior half of length of frontals. Posterior fontanel about 30\% shorter and 10\% narrower (at widest portion) than anterior one (Fig. 6A), delimited mostly by frontals and only posterior end by supraoccipital. Frontals mostly separated from each other at midline by fontanels, contacting at a small portion at their midlength, corresponding to the epiphyseal bar,

Table 3. Morphometric data of Ernstichthys taquari. Range, mean, and SD (standard deviation) include holotype.

\begin{tabular}{lcccccc}
\hline & holotype & $\mathbf{n}$ & min & max & mean & SD \\
\hline Standard length (mm) & 20.2 & 3 & 20.2 & 22.8 & 21.9 & 1.5 \\
Depth at dorsal-fin origin & 24.8 & 3 & 23.3 & 24.8 & 23.9 & 0.8 \\
Snout to dorsal-fin origin & 30.2 & 3 & 28.7 & 30.2 & 29.4 & 0.8 \\
Snout to pectoral-fin origin & 16.8 & 3 & 16.1 & 16.8 & 16.6 & 0.4 \\
Snout to pelvic-fin origin & 36.5 & 3 & 35 & 36.5 & 35.5 & 0.8 \\
Snout to anal-fin origin & 18.8 & 3 & 17.1 & 18.8 & 17.8 & 0.9 \\
Caudal-peduncle depth & 8.6 & 3 & 7.9 & 8.6 & 8.2 & 0.3 \\
Caudal-peduncle length & 20.8 & 3 & 18.9 & 20.8 & 19.8 & 1.0 \\
Pectoral-fin length & 17.5 & 3 & 17.1 & 17.5 & 17.3 & 0.2 \\
Pelvic-fin length & 45.3 & 3 & 44.6 & 45.4 & 45.1 & 0.4 \\
Pelvic-fin origin to anal-fin origin & 14.5 & 3 & 14.2 & 14.8 & 14.5 & 0.3 \\
Dorsal-fin length & 18.8 & 3 & 18.3 & 19.9 & 19.0 & 0.8 \\
Dorsal-fin base length & 35.1 & 3 & 34.9 & 35.6 & 35.2 & 0.4 \\
Anal-fin length & 16.8 & 3 & 15.2 & 16.8 & 15.8 & 0.9 \\
Anal-fin base length & 56.0 & 3 & 55.5 & 56.2 & 55.9 & 0.4 \\
Eye to dorsal-fin origin & 6.6 & 3 & 6.6 & 8.4 & 7.3 & 1.0 \\
Dorsal-fin origin to caudal-fin base & 23.4 & 3 & 22.1 & 23.4 & 22.6 & 0.7 \\
Head length & 32.6 & 3 & 31.3 & 32.6 & 31.9 & 0.7 \\
Horizontal eye diameter & 41.3 & 3 & 41.3 & 43.1 & 41.9 & 1.1 \\
Snout length & 9.1 & 3 & 7.6 & 9.1 & 8.2 & 0.8 \\
Interorbital width & 18.4 & 3 & 18.4 & 22 & 20.5 & 1.9 \\
Upper jaw length & 56.9 & 3 & 56.9 & 62 & 59.4 & 2.5 \\
\hline
\end{tabular}




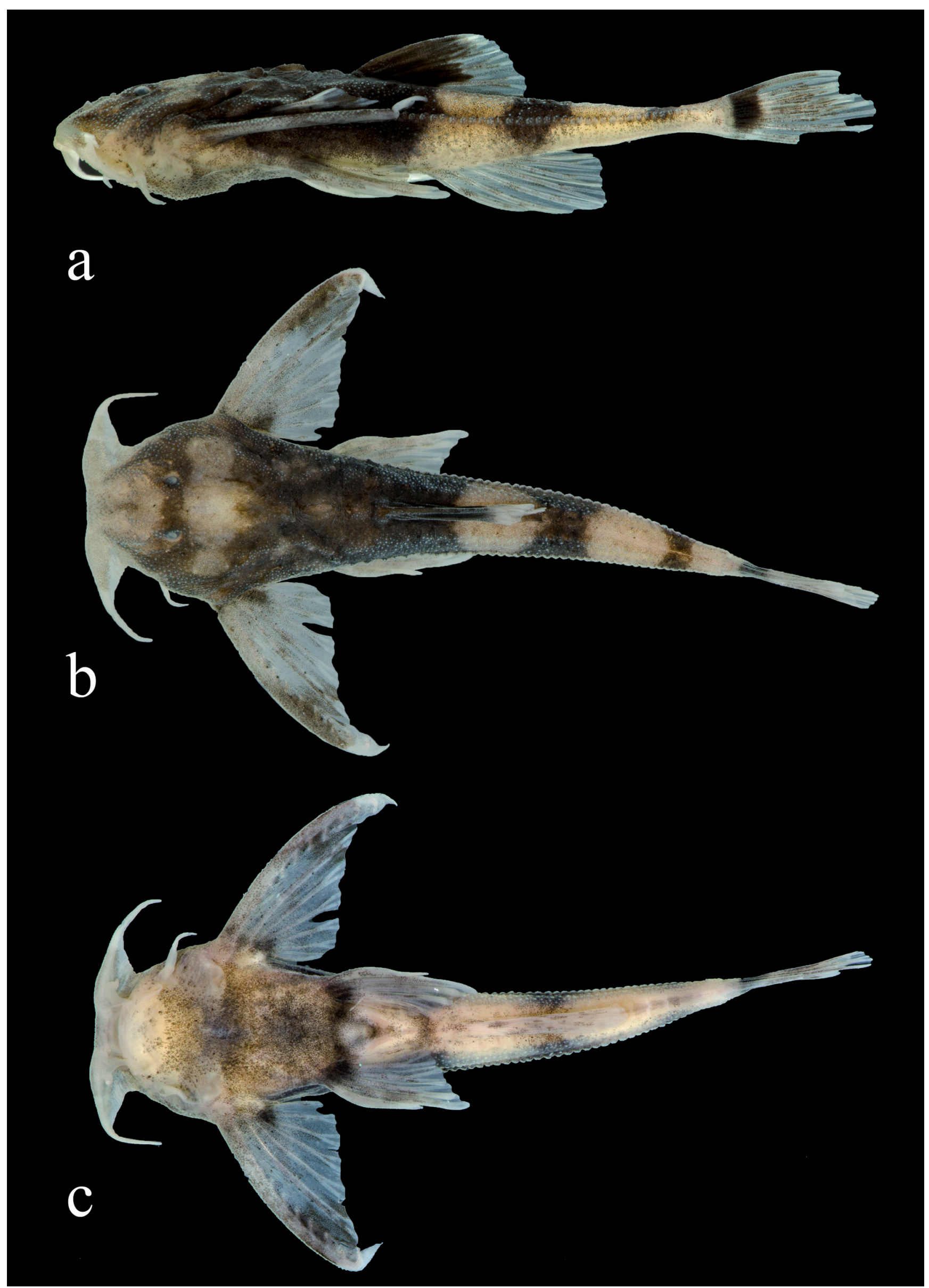

Figure 4. Ernstichthys taquari, Brazil, Mato Grosso do Sul, Alcinópolis, Rio Taquarizinho State, MZUSP 125825, holotype, 22.8 mm SL. (a) Lateral view, (b) dorsal view, (c) ventral view. Photos by V. Reis. 
with two frontals forming $\mathrm{H}$-shaped configuration in dorsal view. Supratemporal fossa (not visible externally) roughly oval, positioned between posterior portion of mesial margin of pterotic and posterior portion of lateral margin of supraoccipital (Fig. 6). Transverse process of vertebra 5 slender, expanded distally and curved slightly posteriorly (Fig. 6A), its distal edge exposed at surface of integument. Eye small, located dorsally on head slightly anteriorly to middle of $\mathrm{HL}$, twice as close to midline as to lateral margin of head in dorsal view (Figs. 4-5). Eye visible only partially in lateral view (Figs. 4-5). Axillary gland pore small, slit-like when collapsed, located immediately posterodorsally to base of pectoral fin. Vent located slightly anterior to transversal through midlength of last pelvic-fin ray. Integument heavily covered with unculliferous papillae on dorsal part of head and dorsal and lateral sides of body, most prominently over area around margins of neurocranium, snout, basal half of dorsal surface of maxillary barbels and cheeks. Unculiferous tubercles homogeneously scattered on body, not arranged in rows or any other regular pattern. Ventral side of head with papillae softer and larger than those on dorsal side of head and rest of body.

Anterior nares encircled by short tubule, longer posteriorly, and separated from each other by distance shorter than interorbital. Posterior nostrils larger than anterior ones, separated from eye by one orbital diameter and partly covered by anteromesial flap of skin. Posterior nares more widely separated from each other than anterior ones, by distance approximately equal to interorbital. Mouth subterminal, slightly wider than interorbital, with both jaws in gentle continuous arcs, and lower jaw shorter than upper jaw. Teeth entirely absent on both jaws. Upper lip well delimited laterally by tumescent maxillary barbel bases, with large irregular-shaped and positioned papillae immediately at mouth opening. Lower lip smooth at edge of mouth but densely large-papillate further posteriorly, with papillate covering extending onto mental region. Mandibles thin and delicate, lacking bony contact at symphysis. Premaxillae shaped as large elongate plates jointly forming nearly continuous concave bony shield internally on upper jaw. Each premaxilla with large stout ascending process near midline, dorsoposteriorly accomodating mesethmoid cornua. Barbels eight: one pair maxillary, one pair rictal and two pairs mental. Maxillary barbel large, flat and expanded basally, forming most prominent feature on head. Maxillary barbel doubly adnate, dorsally from proximal two-thirds of its posterior margin to cheek and ventrally from base of rictal barbel to mental region immediately anterior to anterior mental barbel. Skin folds of adnation forming deep pocket lateral to rictus and anterior to coronoid process of mandible. Rictal barbel short, directed ventrally or ventrolaterally, inserted ventrally at anterior
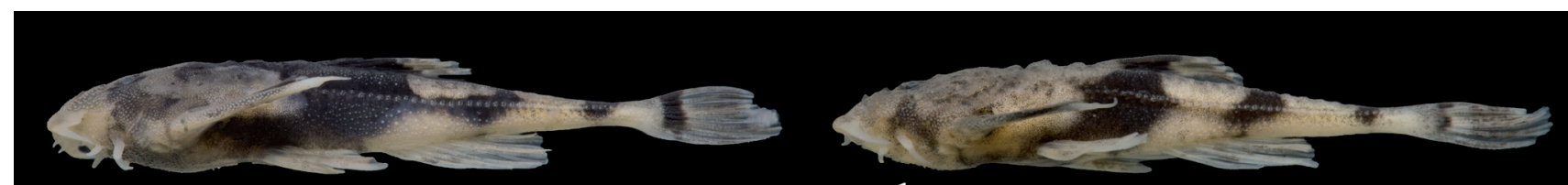

a
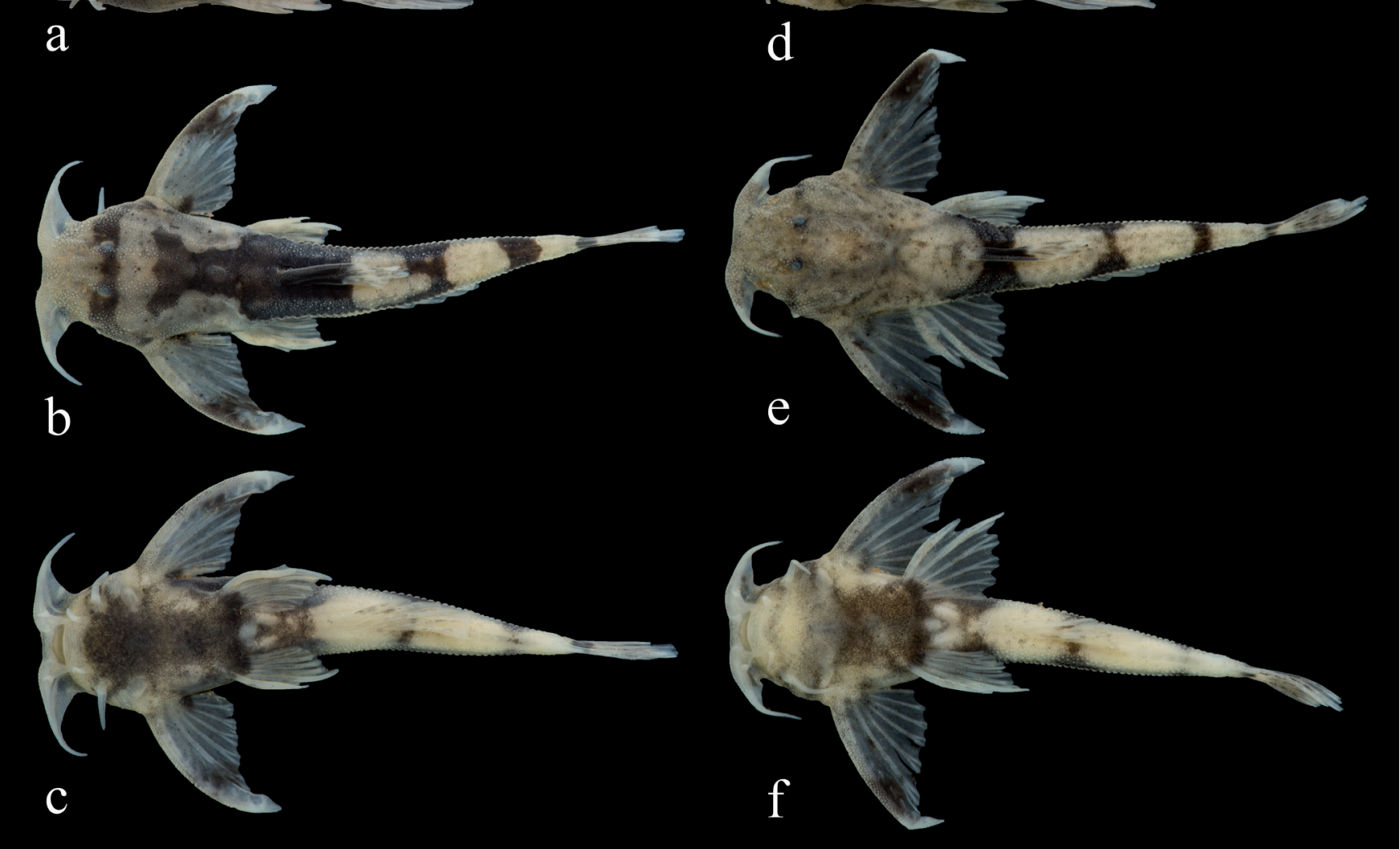

Figure 5. Ernstichthys taquari, MZUSP 125826, paratypes. Left side specimen $20.2 \mathrm{~mm} \mathrm{SL:} \mathrm{(a)} \mathrm{lateral} \mathrm{view,} \mathrm{(b)} \mathrm{dorsal} \mathrm{view,} \mathrm{(c)} \mathrm{ventral} \mathrm{view;} \mathrm{right} \mathrm{side} \mathrm{specimen}$ $22.7 \mathrm{~mm} \mathrm{SL}$ : (d) lateral view, (e) dorsal view, (f) ventral view. 
attachment of ventral adnation of maxillary barbel, Two pairs of mental barbels inserted close to lateral margin of ventral side of head; posterior one twice as long and thick as anterior one. Branchiostegal membranes broadly united to isthmus, without free fold. Gill openings ventral, reduced to small oblique slits anteromedial to insertions of pectoral spines, approximately twice as wide as width of pectoral-fin spine base. Branchiostegal rays four, first one short and thin, attached to middle of anterior ceratohyal. Remaining three branchiostegal rays longer and stouter than first one, attached to posterior end of anterior ceratohyal.

Pectoral fin large, $1+6+i^{*}(3)$, with soft branched rays thin and delicate, shorter than spinous ray but not to same degree as in other species of Ernstichthys. Pectoralfin spine long, $35-36 \%$ of SL, with triangular soft tissue cap distally. Anterior margin of spine smooth, without serrations. Posterior margin with seven large pungent antrorse serrations, progressively larger distally, plus one or two proto-spinous bony bumps basally. Cleithral bullae large and conspicuous, forming widest part of body and head in dorsal view. Postcleithral process large, broad and abruptly narrow and pointed distally, reaching to middle of Weberian centrum in lateral view, and almost to vertical through tip of coracoid process. Posterior coracoid process long, slightly curved mesially distally, its tip reaching half-length of basipterygium and almost to base of pelvic fin. Pelvic fin long and pointed, inserted well anteriorly to vertical through origin of dorsal fin, $i+5^{*}(3)$, with first ray thickest of series and $30 \%$ shorter than second. Second pelvic-fin ray longest of series and thicker than all other rays except first. Basipterygium with long pointed posterior process reaching almost to transversal through anterior tips of first ventral shield. Dorsal-fin origin well anterior to half of SL, entirely adnate posteriorly, to end of last fin ray. Dorsal spinelet (or first spine, or spine lock) absent, first ray (homologous to main dorsal-fin spine) not spinous, flexible, segmented and without serrations. Dorsal-fin rays $1+4^{*}(3)$. Four dorsal-fin pterygiophores broad and angulate in shape, pierced by large irregular fenestrae. Anterior nuchal plate absent. Remaining nuchal plates described above under dorsal shield series (Fig. 6). Adipose fin absent. Anal fin insertion at vertical through end of dorsal-fin base, partly adnate, to ca. two-thirds of last ray, with small free edge at end. Anal-fin rays i+6*(3), third and fourth rays longest. Seven anal-fin pterygiophores progressively smaller posteriorly, four anterior ones squarish and irregularly fenestrated, posterior three rectangular and lacking fenestrae. Caudal fin $5+4^{*}(3)$, with lower lobe longer than upper one as consequence of elongate lower principal fin-rays. Profile of upper lobe straight or gently sinusoidal, that of lower lobe convex and round. All principal rays closely set, nearly adpressed at base. Outer rays thicker and with bases much stouter than that of remaining rays. Procurrent caudal-fin rays represented by single ventral element, spine-like and bent near base. Dorsal procurrent caudal-fin rays absent.

Body armored with three series of bony elements: dorsal, ventral and lateral, all of which heavily cov- ered with integument and not conspicuous on surface of body. Dorsal and ventral series running alongside mid-dorsal and mid-ventral lines, respectively. Lateral series extending along midlateral line of each side of body. Dorsal series formed by 21 heavily ornamented shields extending from immediately anterior to dorsal fin to end of body. Four of those shields disposed alongside base of dorsal fin. First shield of dorsal series formed by greatly expanded posterior nuchal plate, supported by bilateral dorsal processes of vertebra 8. Remaining 20 dorsal shields formed by expanded tips of bilateral dorsal processes (Fig. 6) on vertebrae 9 to compound ural centrum. Anterior fourteen vertebrae-derived shields bilateral, gradually closer together at the midline posteriorly. Posterior six shields median, progressively narrower posteriorly. Elements of dorsal shield series not overlapping each other and not contacting those of lateral series, except for last one which barely touches dorsal margins of penultimate and antepenultimate lateral plates. Ventral shield series with 16 heavily ornamented bony shields, with two anterior ones anterior to anal fin. First shield largest, formed by distal expansions of hemal arch of vertebra 9, broader anteriorly than posteriorly and with concave anterior and posterior margins, its anterior margins produced into anterolateral processes distally approaching posterior processes of basipterygia. Second ventral bony shield immediately anterior to anal fin, lozenge-shaped and formed by distally-expanded first anal-fin pterygiophore. Remaining 14 shields formed by distal expansions of bilateral ventrolateral vertebral processes, extending to posterior-most vertebra anterior to caudal centrum. Of those, nine anterior ones bilateral (six of which disposed alongside anal-fin base) and remaining five ones median, latter clearly formed by confluence of bilateral portions. Posterior five ventral shields broader than long, except for long isosceles-triangular last element. Ventral shields not overlapping each other and not contacting any element of lateral series. Lateral series composed of actual plates or scutes, contrary to dorsal and ventral series, and formed by modified and hypertrophied lateral-line ossicles lacking direct contact with vertebral column. Lateral shields not ornamented and covered with thick integument, not readily visible on external aspect of body. Transition of lateral line tubules into plates gradual, starting at ninth ossicle, approximately at vertical though end of dorsal-fin base, and progressively more expanded towards caudal fin. Overlap among plates starting at ossicle 15, forming complete shield on sides of body from that point on. Total of 34 plates, each with central blunt knob of thickened bone except for last one (Fig. 6), collectively forming lateral serration. Knobs gradually less prominent posteriorly, covered with thick soft skin and concentration of papillae. Knobs centrally located on anterior plates but gradually displaced dorsally starting on $24^{\text {th }}$ plate. Spacing between knobs slightly decreasing towards caudal fin.

Total vertebral count 29 (including those in Weberian complex). Ribs absent. 


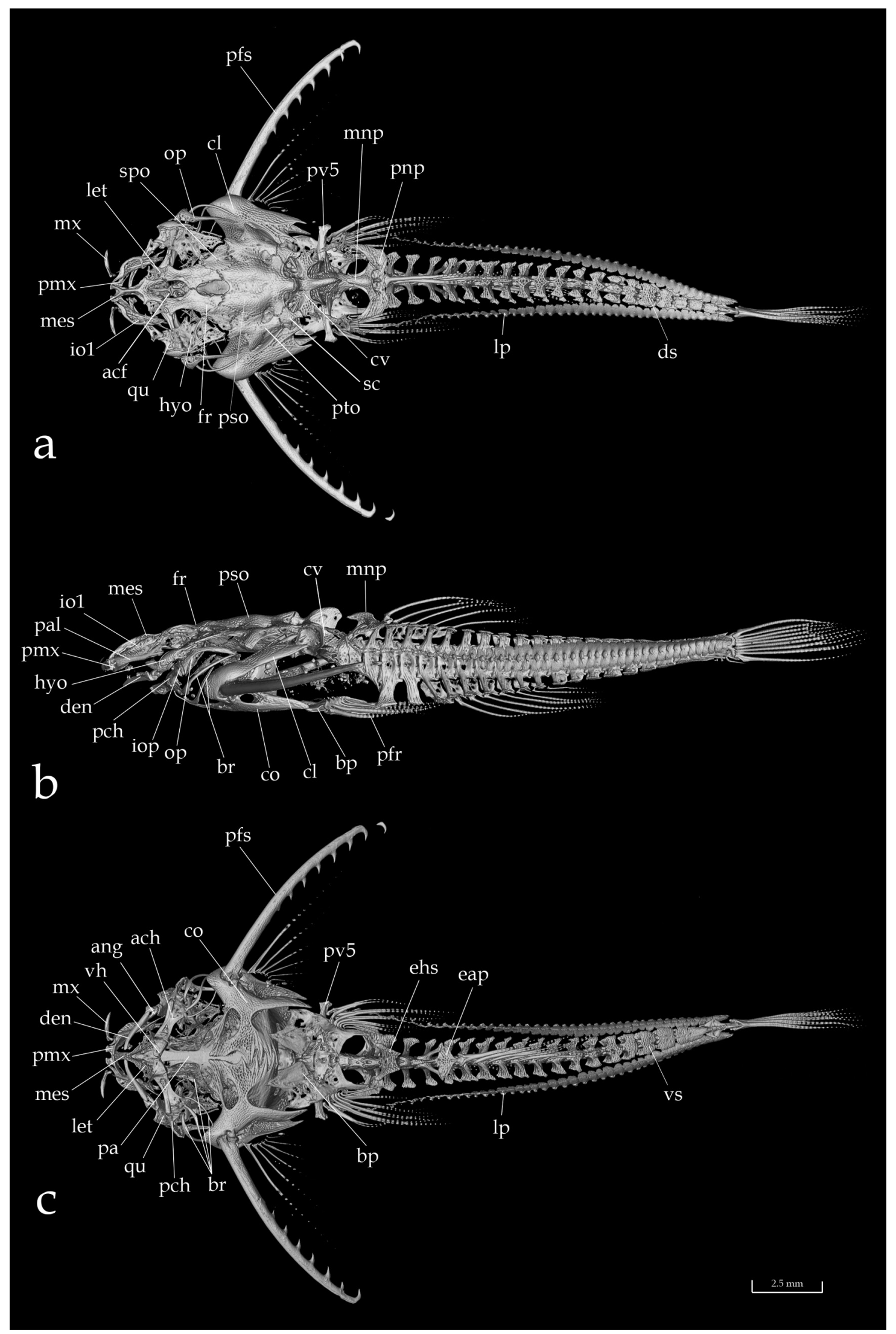

Figure 6. High-resolution x-ray computerized microtomography (HRXCT) of Ernstichthys taquari, MZUSP 125825, holotype, 22.8 mm SL. (a) Dorsal view, (b) lateral view of left side, (c) ventral view. acf: anterior cranial fontanel; ach: anterior ceratohyal; ang: anguloarticular; bp: basipterygium; br: branchiostegal rays; $\mathrm{cl}$ : cleithrum; co: coracoid; cv: complex vertebra; den: dentary; ds: dorsal shield element; eap: expanded first anal-fin pterygiophore (= second ventral shield); ehs: expanded hemal spine (= first ventral shield); fr: frontal; hyo: hyomandibula; io1: first infraorbital; iop: interopercle; let: lateral ethmoid; Ip: lateral plate element (= expanded lateral-line ossicle); mes: mesethmoid; mnp: middle nuchal plate; mx: maxilla; op: opercle; pa: parasphenoid; pal: palatine; pch: posterior ceratohyal; pfr: pelvic-fin rays; pfs: pectoral-fin spine; pmx: premaxilla; pnp: posterior nuchal plate (= first dorsal shield); pso: parietosupraoccipital; pto: pterotic; pv5: parapophysis of fifth vertebra; qu: quadrate; sc: posttemporosupracleithrum; spo: sphenotic; vh: ventral hypohyal; vs: ventral shield element. 


\section{Pigmentation in alcohol}

Pattern of dark pigmentation highly variable. Four conspicuous saddles of dark coloration across dorsolateral surface of body, extending in faded version ventrally and gradually smaller posteriorly. White round areas in dorsal view between first, second and third dark saddles, due to concave profiles of posterior margin of first saddle, anterior and posterior profiles of second one and anterior profile of third one. First dark saddle largest, covering entire area between pelvic- and dorsal-fin bases, extending over basal half, or more, of latter. Dorsal area and shape of saddle variable. In one paratype restricted to doubly-concave band across most of anterior part of dorsal fin, but not to base of spine (Fig. 5E). In other paratype, band covers broad squarish area on and around anterior half of dorsal fin, extending anteriorly continuously as narrow straight mid-dorsal dark band over occipital region and then expanding laterally as bilateral wings over posterior margin of neurocranium (Fig. 5B). In holotype, anterior saddle vast, covering entire dorsum and sides in continuous dark area from anterior $60 \%$ of dorsal fin to posterior third of head. Second dark saddle immediately posterior to end of dorsal fin, extending ventrally and narrowing to end of anal-fin base, its mid-lateral part prolongued anteriorly and in one paratype broadly cojoining anteriorly with first saddle along midlateral line. Third dark saddle beginning approximately at posterior third of caudal peduncle. Fourth saddle smallest, covering region of proximal portions of caudal-fin rays but not reaching last ventral ray. Cheeks with dark cloud extending ventrally towards pectoral-fin base and region around base of posterior mental barbel. In holotype and one paratype, dark cheek fields continuous dorsally with striking transversal dark band across eyes (trans-ocular band), forming conspicuous mask-like pattern. Barbels white, except for uniform dark covering on dorsal surface of proximal half of maxillary-barbel base in holotype and one paratype (Fig. 5E). Axillary gland pore white. Tubercles on dorsal and lateral surfaces of body and head lighter than surrounding areas. Individual bony knobs along lateral-line shield series lighter than rest of adjacent integument, due to concentration of white tubercles. Central part of abdomen almost entirely covered with extensive continuous dark field from base of pelvic fins to mental region, in one paratype with long light losenge-shaped area between bases of posterior mental barbels. Abdominal dark field continuous posteriorly with darker fields on and between bases of pelvic fins and anteriorly fading before lower lip. Area of branchial opening conspicuously lighter than surrounding region. Vent light or white but finely rimmed in dark. Bilateral elongate white fields posterolaterally to vent, converging towards midline posteriorly. Dorsal-fin solid dark on anterior half or $60 \%$, with distal portion covered only with scattered cromatophores over fin rays and hyaline margin. Anal fin mostly white, with faint irregular dark fields not forming any pattern. Caudal fin with dark saddle described above over base of fin rays, followed by narrow white vertical band and then faint irregular dark smudges over rest of fin web, abruptly fading on its distal fifth. Pectoral fin with large dark field crossing distal portion of first soft fin ray and mid-distal adjacent portion of pectoral-fin spine. Small independent dark spot over bases of last four rays. Rest of pectoral fin with scattered dark chromatophores. Distal portion of pectoral-fin spine and soft-tissue terminus abruptly white. Dorsal surface of pelvic fins covered with irregular dark fields denser than those on anal fin. Ventrally, very dark field covering basal portion of rays and region between fin bases, continuous anteriorly with remainder of abdominal dark pigmentation.

\section{Ecology}

Ernstichthys taquari was collected in a white water river, with moderate water flow, over substrate composed of rock and sand. Contrary to most hoplomyzontines, its habitat is not the deep bottom of a large river, but rather a small river accessible by hand-seining. Aquatic macrophytes were present in some sites and riparian forest was well preserved. All specimens were collected in a shaded sector covered with dense vegetation and large rocks on the bottom. The species was not locally abundant at the time of collection, with only three specimens found in the course of five hours of collecting effort.

\section{Etymology}

The specific name taquari is a reference to the rio Taquari. The word is of Tupi language origin (takwa'ri) combining ta'kwara (a common name for bamboo-like plants of family Poaceae) plus ' $i$ ' for diminutive. A noun in apposition.

\section{Remarks}

Intraspecific variation in pigmentation in Hoplomyzontinae has been well-documented in Micromyzon akamai (Chuctaya et al., 2020) and in Hoplomyzon sexpapilostoma (Taphorn \& Marrero, 1990). The variation pattern described for $H$. sexpapilostoma is similar to that in E. taquari, with some individuals with a dark band across the eyes (trans-ocular band) and others without it. This is the same kind of variation here observed in E. taquari (cf., Fig. 5). Taphorn \& Marrero (1990) associated the presence of a differentiated trans-ocular band with females and juvenile specimens. In males, the band is reported to expand and to become undifferentiated from the pigmentation of the rest of head. Another sexually-dimorphic coloration trait observed by those authors in $H$. sexpapilostoma is the size and intensity of the dark spot on the distal portion of the pectoral fin and spine. Taphorn \& Marrero (1990) note that the marking is larger and darker in males. In E. taquari, a single specimen lacking the trans-orbital dark band does not noticeably differ from other specimens in the size of its pectoral fin spot. Unfortunately, the limited number of specimens available does not allow at this time the sex verification of individuals of $E$. taquari. Thus, the possible association of such pigmentation variation with sexual dimorphism 
remains unverified in the species. In any case, the parallel of the two pigmentation patterns of E. taquari with those in $H$. sexpapilostoma are highly suggestive of a similar sexually-dimorphic association.

An unidentified species of Ernstichthys from the Rio Araguaia was reported and illustrated by Jarduli et al. (2014) and hypothesized as sister group to clade E. anduzei + E. megistus (Cardoso, 2008). The photograph in Jarduli et al. (2014, p. 507) shows a fish similar to E. taquari in dorsal and lateral views, but with some visible differences. The strongly bent distal portion of the pectoral spine of the Araguaia specimen, as well as the great length discrepancy between the spine and the soft rays (a common feature in most species of Ernstichthys) are not present in any of the specimens known of E. taquari. Also, the eyes of the Araguaia specimen are noticeably smaller proportionally than those of E. taquari. Finally, the particular color pattern of the Araguaia specimen (with a thin inter-ocular bar but no trans-orbital bar and more or less regular-sized small spots forming a speckled covering on head and dorsum) is also not present in any E. taquari (although not much weight attaches to this difference because of the wide pigmentation variation in species of Hoplomyzontini and the limited number of specimens available). It is impossible at this time to confidently resolve the taxonomic status of the Ernstichthys specimen from the Rio Araguaia illustrated in Jarduli et al. (2014). Preliminary differences noted above, however, suggest that it is not conspecific with E. taquari.

Another report of Ernstichthys in the Brazilian Amazon is provided in Ohara \& Zuanon (2013) on the basis of a single specimen from the Rio Madeira, identified as E. cf. anduzei. As noted by the authors (p. 125), this particular specimen does not conform to $E$. anduzei in the number of dentations in the pectoral-fin spine (nine; vs. 10 to 14). Also, the gentle curvature of the pectoral-fin spine and the relatively gradual length difference between the spine and soft rays both do not match the rather abrupt distal spine curvature and the large length discrepancy between spine and soft rays in $E$. anduzei. In both traits, the Madeira specimen approaches conditions in E. taquari, an obviously more similar taxon. Like in the preceding case, some differences exist that are indicative that the two are not conspecific. First, the pale coloration of the Madeira specimen lacks most dark pigmentation typical of hoplomyzontine species other than those of Micromyzon. Barring some post mortem bleaching of the specimen, this is well beyond the intraspecific variation expected in the group. Second, its number of pectoral-fin spine dentations (nine) is intermediate between E. taquari (7-8) and E. anduzei (10-15). Finally, the pectoral-spine length of that specimen is $31.8 \% \mathrm{SL}$ (measured from the published photograph), thus significantly shorter than that of E. taquari (35-36.5\% SL). The summation of those differences suggests that the specimen of E. cf. anduzei reported in Ohara \& Zuanon (2013) is not a representative of $E$. taquari. As before, however, such evidence is insufficient to properly resolve the question at this time. More material and direct comparisons of specimens are needed.

\section{Geographic distribution}

Ernstichthys taquari is so far known from the type locality in the rio Taquari, tributary of rio Paraguay basin (Fig. 3).

\section{Conservation status}

Ernstichthys taquari is endemic to Brazil and only known from its type-locality at the upper Rio Taquari. Its area of occupancy (AOO) (B2) of $4 \mathrm{~km}^{2}$ is based on this only known record. The AOO is likely underestimated since representatives of the genus are very rare in collections. As discussed above in the corresponding section on Paracanthopoma saci, siltation of the Rio Taquari is the most critical environmental and socio-economic problem in the Pantanal (Soriano et al., 2001). Aspredinidae often occupy specific and rather complex microhabitats and siltation likely extirpates the type of environments that $E$. taquari likely requires. A continuing decline in habitat quality $b$ (iii) is inferred based on the still growing pasture areas and siltation. It is not possible to meet subcriterion ' $a$ ' because the population is not necessarily fragmented. Therefore, we suggest this species is classified as Near Threatened, close to meeting Critically Endangered (CR) by the following criteria B2b (iii) according to the International Union for Conservation of Nature (IUCN) categories and criteria (IUCN, 2020).

\section{DISCUSSION}

The phylogenetic placement of Paracanthopoma saci in Vandelliinae is supported by all synapomorphies so far proposed for the subfamily, a very strongly-corroborated monophyletic group. Those include the dentaries not meeting at the midline; the presence of "claw-like" teeth in the premaxillae; the lack of the fifth ceratobranchial and associated toothplate; the absence of hypobranchials two and three; the toothless upper pharyngeal toothplate; the absence of vomer; the absence of mesocoracoid; and the fully cartilaginous fourth pharyngobranchial (Baskin, 1973; de Pinna, 1998; DoNascimiento, 2012) plus some unique myological synapomorphies (Datovo \& Bockmann, 2010). Finally, the specialized feeding on the blood of other vertebrates, given its uniqueness, is also valid evidence for monophyly, although one which at this point refers to general biology rather than specific character states.

Paracanthopoma is perhaps the most clearly-defined genus in Vandelliinae. The integument fold across the isthmus is an easily-observable character that occurs nowhere else in Vandelliines and has been part of the diagnosis of the genus since its establishment (Giltay, 1935). It is also a unique feature among its closest relatives, the Stegophilinae and Tridentinae. Although nearly all tridentines (except Miuroglanis) and some stegophilines (Acanthopoma, Apomatoceros and Schultzichthys) have superficially similar structures, they all differ from the situation in Paracanthopoma. The membranes in 
Tridentinae are actually free branchial membranes, with completely embedded branchiostegal rays and not attached to the isthmus (or only narrowly attached anteriorly), leaving a large unconstricted branchial opening. In stegophiline taxa mentioned above, the membrane is broadly attached to the isthmus (a condition general in the clade consisting of Stegophilinae and Vandelliinae, none of which has free branchiostegal membranes) and the free flap is clearly a portion of the membrane posterior to the fusion, because it contains embedded branchiostegal rays. The situation is easily verified in alcoholic or c\&s material by lifting the membrane and observing the totally included set of rays in the free flap. The structure is very different in Paracanthopoma. Here, the free fold does not consist of a free branchiostegal membrane, contrary to reported in the original description of the genus (Giltay, 1935) and repeated in several subsequent publications and keys. The actual branchiostegal membrane in Paracanthopoma is nearly entirely fused to the isthmus, leaving the branchial opening reduced to a small passage limited to the region between the opercular and interopercular patches of odontodes, as in all other vandelliines. The integument fold across the isthmus in Paracanthopoma is actually an independent structure that overlays the whole isthmal region. It contains no branchiostegal rays, which are located entirely in the soft tissue anterior to the fusion with the isthmus. The fold forms a broad and deep integument flounce extending continuously across the isthmus, with no embedded rays. The Paracanthopoma fold is probably a derivative of the branchiostegal membrane, but constitutes a set of specialization exclusive to the genus. In order to highlight its neomorphic nature and avoid further confusion with the branchiostegal membrane itself, here we call it a branchiostegal velum.

Comparative examination of the anatomy of Paracanthopoma reveals other putative synapomorphies for the genus in the skeleton. For example, species of the genus (including all new taxa known to us) have a distally bifurcated maxilla, a unique configuration among the otherwise single-headed maxillas of other vandelliines and trichomycterids in general. Their median premaxilla is also different from that of all other vandelliines and stegophilines (the only taxa having that structure) in having bilateral dorsal flanges bracing the neck of the mesethmoid immediately posterior to the mesethmoid cornua. The median premaxilla in other taxa lacks an elaborate dorsal surface of that bone (a non-homologous median process is present in most stegophilines). A complete phylogenetic evaluation of Paracanthopoma lies beyond the scope of the present paper, but a hypothesis of its monophyly is well-supported by a few unique, uncontradicted and well-defined character conditions (in addition to the characters above, an additional list is provided in DoNascimiento, 2012, not explicitly enumerated here because that work is still unpublished). Of course, not all unique characteristics shared between $P$. saci and P. parva will necessarily be synapomorphic for the entire genus once its species diversity is more completely mapped, because some will be synapomorphic for subsets of the genus (a discussion of this topic, in the context of $P$. parva and one of the undescribed species, is provided in DoNascimiento, 2012). Regardless of such factors, little doubt exists that $P$. saci is the closest relative of $P$. parva among currently-known vandelliine diversity.

Species-level distinction between $P$. saci and $P$. par$v a$ is well-corroborated by a series of conspicuous differences in various body systems, as summarized in the Diagnosis above. The distinctions are pronounced in kind and degree, resulting in fishes with very different general aspect and which can be distinguished at a glance with the naked eye, despite their small size. Examination of series of $P$. parva (cf., Comparative Material) plus $15 \mathrm{spec}$ imens of $P$. saci demonstrate that none of those diagnostic characteristics is subject to intraspecific variation sufficient to bridge the gaps between the two species. In fact, the profound differences in body and head structure suggest species with quite different biologies. The delicate mouth dentition of $P$. saci is probably associated with a specialization on smaller hosts and perhaps subtle approaching strategies, when compared with the brutish oral armature of $P$. parva. Also, the spatulate caudal peduncle is indicative of a swimming mode based on propelling by the posterior part of the body, rather than by undulations of the entire body. All those factors indicate that considerable divergence exists between the two species of Paracanthopoma. In fact, species diversity of the genus is substantially larger than presently documented not only in species numbers but also in phenotypic divergence, as an ongoing revision of the group by the authors confirms.

Hoplomyzontinae is a strongly-supported monophyletic group. Its corroborating synapomorphies are not only numerous and diverse, but they are also highly conspicuous. Their body armor, for example, is unique among aspredinids. Although some other catfish groups also have a body armor, such as distal loricarioids (Callichthyidae, Scoloplacidae, and Loricariidae), Doradidae, Amphiliidae (Doumeinae), and Sisoridae (Sisor), structural details of the armor in hoplomyzontines are unique. They are the only mailed catfishes where the bony shielding is formed by a combination of emerging vertebral expansions (dorsal and ventral shield series) and independent plates formed from modified lateral-line ossicles in the lateral series (Friel \& Lundberg, 1996). Other undisputed synapomorphies for the subfamily include the absence of ribs, absence of urohyal, 5+4 principal caudal-fin rays, premaxilla with an anterior limb, the anterior displacement of the pelvic fin and girdle so that the basipterygia lie very close to the coracoids, partly included between coracoid processes (Friel, 1994). Ernstichthys taquari shares all those synapomorphies and little doubt remains as to its placement in Hoplomyzontinae.

The generic allocation of the new species needs more detailed discussion because the relevant set of evidence is less decisive than that for the subfamily level. The long pectoral-fin spine is the most visible similarity that E. taquari shares with other species currently in Ernstichthys. This is clearly an apomorphic condi- 
tion. Other hoplomyzontines allocated in Hoplomyzon, Micromyzon, and Dupouyichthys have a proportionately much shorter spine, similar in that regard to that in other aspredinids and catfishes in general. Although the pectoral-fin spine in E. taquari is more similar to that of congeners than to that of other genera in the subfamily, it is also noticeable that its condition is the least extreme in the genus. Other species of Ernstichthys have a comparatively longer and more distally curved spine, approximately twice as long as the rest of the fin. Also, in E. taquari the size discrepancy between the pectoral-fin spine and remaining fin rays is not as dramatic (Figs. 4-5). Thus, the situation of the pectoral fin in E. taquari is intermediate between the state in other Ernstichthys, on the one hand, and the one in remaining hoplomyzontines, on the other. Friel (1994) lists as an unambiguous synapomorphy for Ernstichthys an expanded and distally-flared transverse process of the fifth vertebra, different from the thin and evenly wide process of other hoplomyzontines. Ernstichthys taquari clearly shares the distally expanded transverse process of the fifth vertebra (Fig. 6A).

A few other characteristics are corroborative of that allocation, although they must be considered as provisional at this point because relevant comparative information is not available for all hoplomyzontine species. For example, the shape of the coracoid process, broad for most of its length and then pointed at the tip, is very similar in E. taquari and other Ernstichthys species (cf., Taphorn \& Marrero, 1990: fig. 2C) and different from the blunt, medially-curved shorter process in other hoplomyzontine genera (cf., Taphorn \& Marrero, 1990: fig. 2A; Carvalho et al., 2016: fig. 4A; Carvalho et al., 2017: fig. 4A). It also deserves notice that the structure of the basipterygium in $E$. taquari is very similar to those of at least some other congeneric species, with a broadly-triangular anterior arm directed straight towards the posterior surface of the coracoid (cf., Taphorn \& Marrero, 1990: fig. 2C). This is different from the condition in hoplomyzontines allocated in other genera, where the anterior arm of the basipterygium is very short and poorly differentiated from the rest of the bone, or narrow and directed anterolaterally (cf., Taphorn \& Marrero, 1990: fig. 2A; Carvalho et al., 2016: fig. 10, 2017: fig. 10).

Much weight has been given to so-called preanal bony "plates" (actually not always true plates, see above) in hoplomyzontine taxonomy, which are serially positioned, medially and bilaterally, anterior to and alongside the base of the anal fin. Those shield series are in fact morphologically heterogeneous, some shields formed by expanded median vertebral processes or hemal spines, others by lateral vertebral processes, and finally some from anal-fin pterygiophores. It has been noted that much intraspecific variation exists in the morphology of those shields (Friel \& Lundberg, 1996: 647) and much of that variation remains uncharted. A majority of the shields are just the endpoints of much larger internal structures that reach the surface of the integument. Part of the observed variation, both intra- and inter-taxonomically, is a result of whether or not, and to what degree, the terminal structures emerge at the surface. Despite such caveats, some information from the preanal shields is certainly useful taxonomically and, if properly studied, helps to further test the generic affinities of $E$. taquari. The anteriormost preanal shield is a median vertebral derivative formed from a distally expanded hemal spine (see Description above). In E. taquari, that shield is as long as broad or slightly longer than broad, has long diverging arms anteriorly (around the anal and urogenital openings area) and its anterior and posterior margins are strongly concave. This is the same overall shape seen in $E$. anduzei and E. megistus, but not in E. intonsus, where it is arc-shaped, much broader than long, concave anteriorly and convex posteriorly (cf., Stewart, 1985: figs. 1D-F; Taphorn \& Marrero, 1990: fig. 3C). Although not present in all species currently in Ernstichthys, the peculiar shape of the first preanal shield is not present in any other hoplomyzontine, thus constituting valid evidence of relationships. The second (middle) shield, also a hemal spine derivative, is long and narrow in E. taquari, E. megistus and $E$. intonsus, but in E. anduzei it is variable, either long as in congeners or roundish (Stewart, 1985: 15). The middle preanal shield is also somewhat elongate in $M$. akamai (Friel \& Lundberg, 1996: fig. 4) but not to the same degree as in species of Ernstichthys listed above.

The dorsal and ventral bony shield series in all specimens known of Ernstichthys taquari differ from those of all congeners in being comparatively narrow, thus failing to overlap or contact each other along most of the two series except the posterior, medially-united elements. In most other hoplomyzontines, the plates contact or even broadly overlap their neighbors. This trait in fact differentiates E. taquari from all other hoplomyzontines except species of Hoplomyzon, which also have narrow, non-contacting dorsal and ventral shields. However, details of the shape of the plates differ in E. taquari and Hoplomyzon species. In Hoplomyzon, the shields are roundish and symmetrical in shape (Carvalho et al., 2017). In E. taquari, contrastingly, the respective plates are roughly triangular and slanted posteriorly. This detail approaches the condition in E. taquari to that in its congeners, regardless of the discrepant non-overlapping condition. In fact, the situation of the dorsal and ventral shields in the species seems like an attenuated form of that in other species of Ernstichthys.

Ernstichthys taquari also shares characters states at more inclusive clades within hoplomyzontines that include the hypothesized closest relatives of its genus. For example, the species lacks premaxillary and dentary teeth, like Dupouyichthys, Micromyzon, and other Ernstichthys. The significance of this trait, however, is not as decisive as it once was, because Hoplomyzon cardosoi also lacks teeth on both bones (Carvalho et al., 2017).

Naturally, a decision about the generic allocation of Ernstichthys taquari depends not only on positive evidence for its alignment with Ernstichthys, as done above, but also on the lack of evidence for alternative placements. Accordingly, the species was investigated as to the presence of diagnostic characters so far proposed for other hoplomyzontine genera. Hoplomyzon has been diagnosed by many characteristics in various pub- 
lications, however a recent reevaluation (Carvalho et al., 2017: 12-13) concluded that a single characteristic is actually apomorphic and confirmed in all species of the genus: the presence of large well-defined papillae disposed along the margin of the upper jaw. This is a trait which has been traditionally used to diagnose the genus since its description (Myers, 1942) and which is not present in any species of Ernstichthys, including E. taquari.

The genus Dupouyichthys, with its single species, $D$. sapito, is the least known hoplomyzontine genus. The configuration of the preanal plates in $D$. sapito was considered as synapomorphic for the genus by Stewart (1985) while Friel (1994) considered the presence of a single such pair as equally diagnostic. To that it might be added that the club-shape and orientation of the bilateral shields on each side of the first (median) preanal plate (Stewart, 1985: fig. 1C) are also unique among hoplomyzontines. The same probably also holds for the rough lozenge shape of the first and second preanal shields in the species (with reservations about possible yet unmapped intraspecific variation). In any event, none of those particularities typical of Dupouyichthys are present in E. taquari. The fourth and final hoplomyzontine genus, Micromyzon, has recently been phylogenetically rediagnosed in Carvalho et al. (2016) by the following traits: eyes absent; lateral margin of frontal straight, not forming an orbital concavity; posterior cranial fontanel reduced or absent; premaxilla absent or extremely reduced; limb of autopalatine posterior to lateral ethmoid articulation about one fourth the length of anterior limb; rows of large tubercles absent along posterior lateral line; dark integumentary pigmentation reduced or absent. Except for the orbital concavity character, which is present (albeit reduced) in the specimen examined of M. akamai, all other characters are consistent with the observations made in association with this paper. As before, E. taquari lacks each and all of those putative Micromyzon synapomorphies. In sum, E. taquari does not bear any convincing character evidence for its inclusion either in Hoplomyzon, Dupouyichthys or Micromyzon. Therefore, the anatomy of $E$. taquari not only provides evidence that is the closest relative of species currently allocated in Ernstichthys, but also reveals no evidence for alternative generic placements.

\section{Biogeographic framework}

Ernstichthys taquari is the first Hoplomyzontinae species reported for the southern half of South America. The subfamily is otherwise a typical component of northern basins of the continent, with nearly its entire diversity in the Amazonas-Orinoco (Fig. 3). The presence of the genus Ernstichthys in the rio Paraguay basin and in the rio Araguaia basin (Jarduli et al., 2014), is congruent with the pattern proposed for the group in Dagosta \& de Pinna (2019). In that paper, Ernstichthys was one of the examples corroborating the pattern called "Cis-Andean Foothills", composed of taxa with distributions restricted to the uplands of the western region of South America, mainly in basins draining the Andean region. In addition to the examples by Dagosta \& de Pinna (2019), other corroborative taxa include Gephyrocharax (Ferreira et al., 2018), Brycon hilarii and B. whitei (Lima, 2017) and the siluriforms Lamontichthys (Paixão \& Toledo-Piza, 2009), Otocinclus huaorani (Schaefer, 1997), O. vittatus (Schaefer, 1997), Pimelodella howesi (Slobodian, 2017), and Rhamdia poeyi (Silfvergrip, 1996). The Cis-Andean Foothills distribution pattern forms an arc with the concavity directed towards the Amazonas-Orinoco (Dagosta \& de Pinna, 2019: fig. 21a). The extension of the arc varies among taxa, mainly in its southern and eastern reaches. Some of those groups have a presence also in the Paraná-Paraguay (e.g., Astyanacinus spp. - here considered as a valid genus - Brycon hilarii, Gephyrocharax spp., Leporinus striatus, Rhyacoglanis spp.), or Tocantins (Lamontichthys spp., Rhamdia poeyi, Xyliphius spp.), although most examples have their southern limit in tributaries of the rio Madeira. As hypothesized by Vari (1988), it is likely that species with that pattern of distribution are limited by ecological requirements associated with swiftly flowing rivers. Indeed, species of Ernstichthys have been included in the guild of rheophilic fishes by Lujan \& Conway (2015). The type locality of Ernstichthys taquari is also the source of the first record of the genus Paracanthopoma (Fig. 3; records for the genus from material directly examined for this study plus data on undescribed species from an ongoing revision of Vandelliinae by the authors) outside of the Amazonas-Orinoco axis. Ernstichthys clearly has a CisAndean Foothills distribution associated with highlands. Contrastingly, Paracanthopoma is a lineage broadly distributed in the Amazonas-Orinoco, with both highland and lowland species (most yet undescribed).

Though exceptional, the presence of those two typically Amazonian lineages (Fig. 3) in a tributary of the Pantanal Wetland is not unique. It has been known for a long time that the headwaters of the Rio Paraguay include some odd Amazonian components, usually restricted in distribution (Lima et al., 2007; Ribeiro et al., 2013; Lopes et al., 2020). The ecological barrier represented by the Pantanal Wetland prevented such upper-water course, clear water, high-energy, components from spreading to the rest of the basin, thus explaining their narrow endemism. The presence of Ernstichthys taquari and Paracanthopoma saci are eloquent additional elements in that pattern.

The lack of a phylogenetic hypothesis for species of Ernstichthys and Paracanthopoma (as mentioned above, there are several undescribed species in the genus) is not a full impediment in understanding the general features of their associated biogeographic history. Important parts of that history can be inferred from ancestral biogeographic reconstructions based on the phylogenetic position of the genera in their respective families. The two genera are exclusively Amazonian, although their sister genera are not: Parandellia in the case of Paracanthopoma and Dupouyichthys in that of Ernsticthys.

Ancestral biogeographic reconstruction from the BBM model (Fig. 7A, D) indicates that the two new spe- 
cies likely arrived secondarily in the Paraguay basin from the Amazonas-Orinoco-Guiana. Model S-DIVA on the other hand, results in a $50 \%$ probability that Ernsticthys taquari is in the rio Paraguay basin by geodispersal, coming from the Amazonas-Orinoco-Guiana and $50 \%$ that its presence there is the result of vicariance (Fig. 7B).

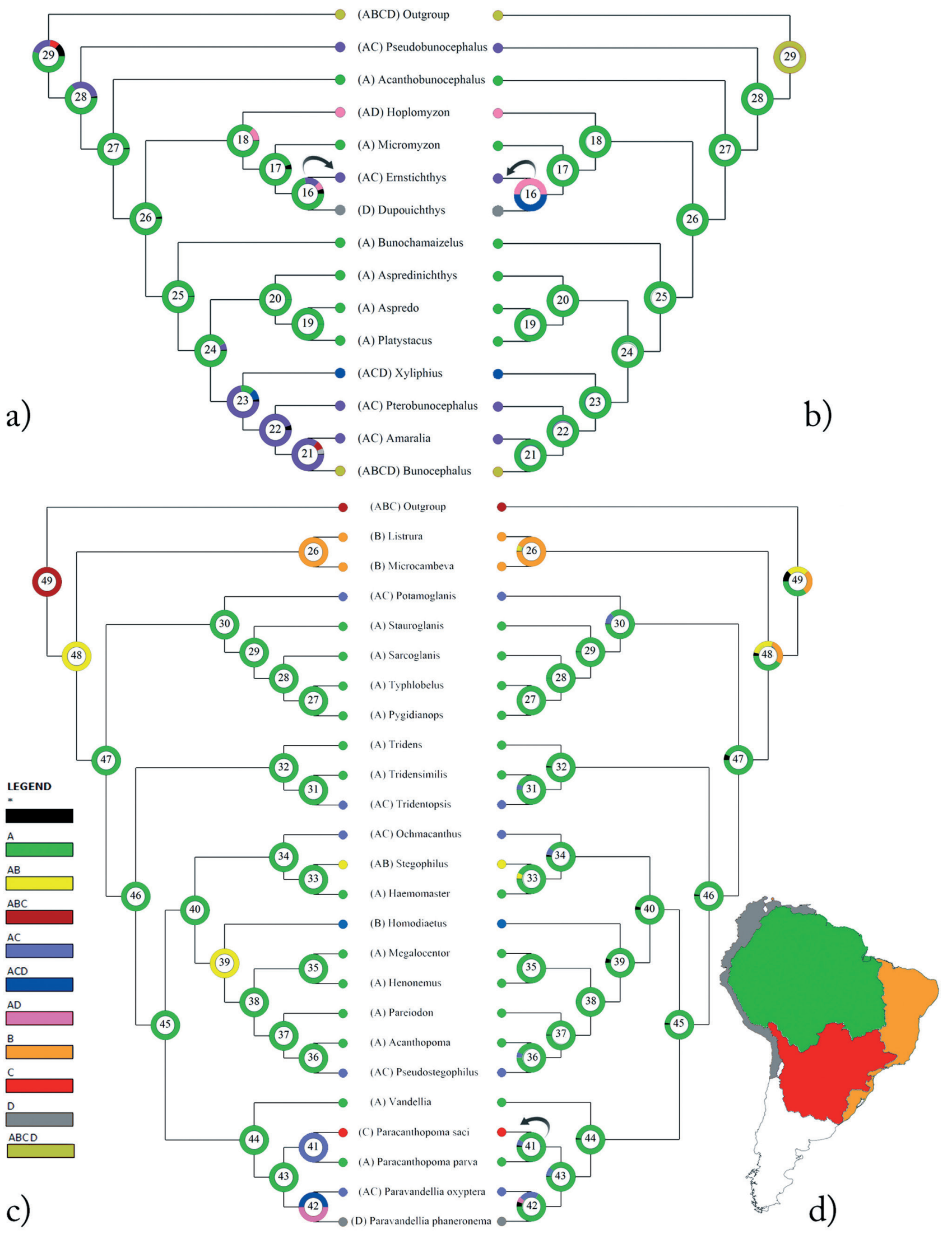

Figure 7. Ancestral geographic reconstruction from Aspredinidae using BBM (7A) and S-DIVA (7B) and from the MTSVG clade of Trichomycteridae using S-DIVA (7C) and BBM (7D). Biogeographical regions: $A=$ Amazon-core; $B=$ São Francisco and Eastern Coastal drainages; $C=$ Paraná-Paraguay; $D=$ Trans-Andean. Black arrows indicate biotic dispersal from Amazon-core to Paraná-Paraguay region. See Materials and Methods section for further analytic details. 
Resolution of that uncertainty must await resolution of the phylogenetic position of the species among other species of Ernstichthys. In the case of Paracanthopoma saci, S-DIVA infers that its presence in the Paraguay results from vicariance, on the occasion of its separation from the Amazonas-Orinoco-Guiana (Fig. 7C). Because several species of Paracanthopoma await description (MdP, pers. obs.) all of which from the Amazonas-OrinocoGuiana region, this biogeographic scenario will be tested once more taxa are included in the analysis. Again, the phylogenetic position of $P$. saci in its genus is key to a resolution of the question.

Despite some degree of uncertainty, a majority of resolutions support the hypothesis that both Ernsticthys taquari and Paracanthopoma saci reached the Paraguay secondarily, from Amazonian ancestors. Although an opposite scenario is theoretically possible (i.e., that those genera arose in the Paraguay and subsequently colonized the Amazon), such hypothesis requires multiple cases of lineage extinction in the Paraguay and is not supported by any of the results. The unlikeliness of such idea is compounded by the fact that the Paraguay is by no means a depauperate basin in terms of fish species and lineages (Fig. 7).

The occurrence of both Ernstichthys and Paracanthopoma exclusively in the upper rio Taquari may suggest a biogeographical history separate from other tributaries of the Paraguay system, even if the acquisition of these Amazonian components is not necessarily related with a single biogeographical event (i.e., they are not necessarily biographically homologous). The Taquari river basin is therefore a hybrid biogeographical unit, with part of its ichthyofaunistic composition related to the Paraguay river basin, of which it is currently tributary, and part associated to past connections with the Amazon.

Both Ernstichthys and Paracanthopoma are absent in neighboring tributaries of the rio Paraguay and upper rio Paraná, but present in the rio Araguaia, an Amazonian tributary. This places the latter basin as a prime candi-

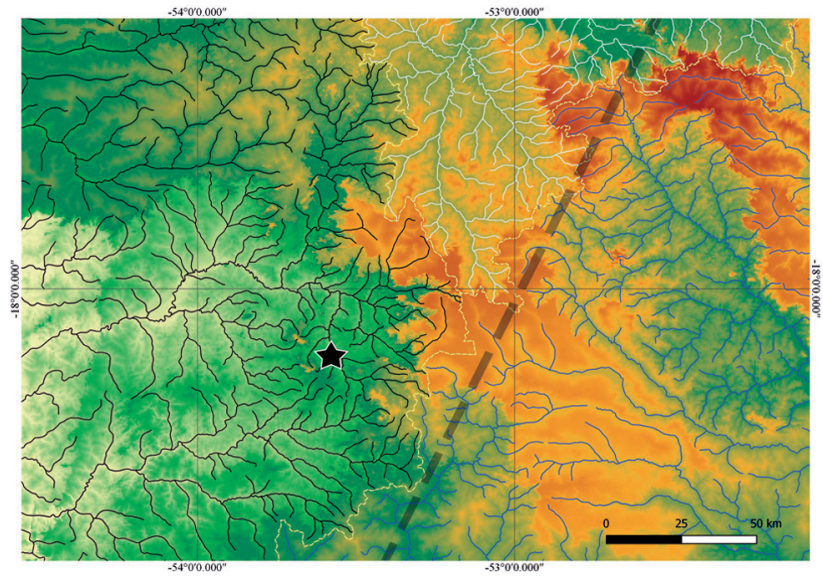

Figure 8. Water divide between upper Paraguay (black rivers), upper Paraná (blue rivers), and upper Araguaia (white rivers). Gray dash-line represents the Trans-brazilian lineament. Thin yellow dashed line means water divide boundaries between neighbouring basins. Black star shows type locality of Ernstichthys taquari and Paracanthopoma saci. date for potential faunal exchange with the Taquari basin. The physical proximity between the headwaters of the rio Taquari with its neighboring Amazonian basins is extreme (Fig. 8), in some cases only a few hundred meters. It is intuitively obvious that headwater stream capture resulted in the presence of Amazonian elements in the upper rio Taquari. Such events are often associated with the upper reaches of adjacent basins and is largely responsible for the historically reticulate nature of river drainages (Lima \& Ribeiro, 2011; Ribeiro et al., 2013; Dagosta \& de Pinna, 2017) (Fig. 8).

The region where both Ernstichthys taquari and Paracanthopoma saci were collected in the upper rio Taquari is located close to the Trans-brazilian lineament, a major geological suture zone where Precambrian faults have been reactivated during the Paleozoic, Mesozoic, and Cenozoic (Paranhos-Filho et al., 2013). Such reactivations are known to have caused the formation of the Pantanal (Assine \& Soares, 2004), with wide-scale hydrological reorganization and rampant headwater capture events in adjacent uplands (Ribeiro et al., 2013). Topography shown in Fig. 3 clearly shows that the upper rio Taquari is located at the border of the Pantanal Wetland depression and the presence of Ernstichthys taquari and Paracanthopoma saci are possible additional elements in that pattern.

\section{Conservation of a highly endemic, poorly known and threatened region}

The two new species herein described are from the rio Taquari, a river which is part of the Pantanal Wetland system but which drains an area of Cerrado biome where the species were collected. The locality is part of the region delimited and named by Dagosta et al. (2020) as "Upper Araguaia". The region corresponds to the uppermost part of the rio Araguaia drainage, upstream of various waterfalls and rapids such as the falls of Couto Magalhães at Santa Rita do Araguaia (State of Goiás). Despite its name, the "Upper Araguaia" bioregion includes also headwaters of tributaries of the Paraguay basin, as the rio Correntes and the rio Taquari, which drain the eastern limit of the Pantanal Wetland.

In addition to the two species herein reported, a number of other fish endemics occur in the Upper Araguaia bioregion, such as Astyanax joaovitori, Characidium chicoi, Cyphocharax boiadeiro, Eigenmannia correntes, Hyphessobrycon eilyos, H. langeanii, H. weitzmanorum, Aspidoras velites, A. taurus, Cnesterodon septentrionalis, Melanorivulus litteratus, M. urbirajarai, Simpsonichthys cholopteryx and other three species of Characidae yet undescribed (F. Dagosta, pers. comm.). This density of endemics is the main factor accounting for the delimitation of that area as a biogeographically distinct unit in the analytical estimates implemented by Dagosta et al. (2020). In fact, it is one of the smallest fish bioregions recognized in South America. Besides its small area and abundance of endemics, the Upper Araguaia bioregion was highlighted by the authors as an Endemic Amazonian 
Fish Area (EAFA) with priority for conservation. That qualification is based on the scarcity of protected areas in the region, the presence of threatened species (e.g., Melanorivulus litteratus and M. urirajarai), and - mainly - deforestation pressure and dam construction. The two latter threats are particularly severe in hydrographic basins draining the Cerrado biome, were a major portion of the agribusiness output and electricity generation is located in Brazil (Latrubesse et al., 2019). The region where Paracanthopoma saci and Ernstichthys taquari were collected has large-scale cattle farming as the main economic activity. On the other hand, the "Amazonian" portion of the "Upper Araguaia" bioregion has a predominance of large monocultures such as cotton and sugar cane. The entire bioregion is dotted with planned small hydroelectric dams, some of which already in place. Therefore, multiple factors demonstrate the Upper Araguaia bioregion is in imminent danger of major biodiversity loss and urgently requires conservation measures.

Finally, it is remarkable that the rio Paraguay basin is considered as a relatively well-sampled system, with a well-known fish fauna. The discovery of such conspicuous elements as the new species herein reported demonstrates that fish biodiversity in the Paraguay drainage and in central Brazil is still underestimated.

\section{Comparative material}

Hoplomyzontinae: Micromyzon akamai, MZUSP 48550, 1 ex, holotype, Brazil, Pará, Rio Tocantins, above confluence with Rio Pará $\left(01^{\circ} 50^{\prime} \mathrm{S}, 49^{\circ} 17^{\prime} \mathrm{W}\right)$, col. A. Akama et al., 20 Nov 1994; MZUSP 48551, 3 ex, paratypes, collected with holotype; MZUSP 48552, 1 ex, paratype, c\&s, Brazil, Pará, Rio Amazonas, south side of river, across from Monte Alegre, ca. $52 \mathrm{~km}$ downriver from mouth of Rio Tapajós $\left(02^{\circ} 01^{\prime} \mathrm{S}, 5^{\circ} 05^{\prime} \mathrm{W}\right)$, col. A. Akama, A. Zanata, 04 Nov 1994. Ernstichthys sp. MZUSP 37814, 7 ex (1 c\&s), Brazil, Mato Grosso, Igarapé Ingazeiro, 20 km upstream from mouth of Rio Canumã on Rio Ariuanã, below Dardanelos (Rio Madeira basin) (09 $\left.58^{\prime} \mathrm{S}, 5^{\circ} 19^{\prime} \mathrm{W}\right)$, col. Joint MZUSP/INPA expedition, 17 Nov 1976; MZUSP 74184, 1 ex, Brazil, Amazonas, Rio Madeira, col. A. Zanata et al. Hoplomyzon sexpapilostoma, MZUSP 38894, 5 ex paratypes, Venezuela, Barinas, Río Masparro, col. D. Taphorn, C. Lilyestrom, 13 Nov 1983.

Trichomycteridae, Stegophilinae (all from Brazil): Acanthopoma annectens, MZUSP 55706, 2 ex, Amazonas, Rio Solimões, col. J. Lundberg et al., 12 Nov 1993. Apomatoceros alleni, INPA 16695, 1 ex, Amazonas, Rio Solimões, Costa da Terra Nova, Lago Castanho, col. M. de Pinna and L. Py-Daniel, 19 Mar 2001. Schultzichthys bondi, FMNH 105572, 31 ex, Ecuador, Rio Napo at Coca, col., D. Stewart and M. Ibarra, 01 Oct 1981.

Trichomycteridae, Tridentinae: Miuroglanis platycephalus, MZUSP 7805, 3 ex (1 c\&s), Brazil, Amazonas, Parintins, col. Expedição Permanente da Amazônia. Tridens mela nops, INHS 40467, 3 ex, Peru, Loreto, Río Nanay (Río
Amazonas drainage), col. B.M. Burr et al., 09 Aug 1996. Tridentopsis cahuali, MNHNP 1448, 12 ex, Paraguay, Presidente Hayes, Pozo Colorado, col., O. Romero et al., 20 Apr 1996. Tridentopsis pearsoni, CAS 56200, 3 ex, Bolivia, Beni, Lake Rogoagua, col. N.E. Pearson.

Trichomycteridae, Vandelliinae: Paracanthopoma parva. Brazil: IRSNB 10121, 2 ex, holotype and paratype, Brazil, upper Rio Catrimani (Rio Branco drainage), col. C. Lako; CAS 118205, 1 ex, Amazonas, upper Rio Catrimani (Rio Branco drainage), col. S. Lako; INPA 16555, 2 ex (1 c\&s), Roraima, Boa Vista, Maracá, Rio Branco, col. O. Bitar, May 1988; MZUSP 30400, 10 ex (3 c\&s), Rondônia, Independência, main channel of Rio Machado (Rio Madeira drainage), col. M. Goulding, 06 May 1978; MZUSP 29793, 2 ex, Amazonas, Rio Negro at Cachoeira de São Gabriel, col. M. Goulding, 18 May 1979; MZUSP 63076, 25 ex (4 c\&s), Mato Grosso, Nova Mutum, Rio Arinos (Rio Tapajós drainage), col. H.F. Mendes, 16 Jan 1998; MZUSP 40585, 29 ex (5 c\&s), Goiás, Monte Alegre de Goiás, Rio Paraná above the mouth of Rio Bezerra (Rio Tocantins drainage), col. J.C. de Oliveira \& W.J.E.M. da Costa, 10 Jan 1989; MZUSP 74624, 13 ex, Mato Grosso, Rio Xingu, Parque Indígena do Xingu, Posto Diauarum, col. G.R. Kloss, 08 Dec 1973. Ecuador: FMNH 99519, 2 ex, Río Aguarico, near Destacamento Militar Cuyabeno and confluence of Río Cuyabeno and Río Aguarico (Río Napo drainage), col. D. Stewart et al., 21 Oct 1983. Guyana: ANSP 179207, 2 ex, Rupununi (Region 9), Ireng River, $6.9 \mathrm{~km}$ WSW of village of Karasabai $\left(04^{\circ} 01^{\prime} 10^{\prime \prime} \mathrm{N}\right.$ 59³6'06"W), col. M.H. Sabaj et al., 01 Nov 2002. Peru: MUSM 4562, 3 ex Madre de Dios, Parque Nacional Manu, Manu, Pakitza, Río Manu, col. H. Ortega, 22 Jun 1993. Paravandellia oxyptera. MZUSP 9597, 1 ex, Brazil, Amazonas, Anamã, Rio Solimões, col. EPA, 21 Sep 1968; MZUSP 23352, 1 ex, Brazil, Amazonas, Rio Solimões, in front of Jacaré, near Fonte Boa, col. EPA, 07 Oct 1968; MZUSP 83703, 8 ex (2 c\&s), São Paulo, São Carlos, Ribeirão das Araras (Rio Grande drainage), col. J.L. Birindelli et al., 09 Oct 2002; MZUSP 89973, 1 ex, Mato Grosso, Tangará da Serra, Rio Sepotuba, below Salto das Nuvens (14³7'15"S, 57²4'20"W), col. H.A. Britski et al., 09 Mar 2002; MZUSP 90600, 2 ex, Mato Grosso, Cáceres, Rio Sepotuba (middle course) (Rio Paraguai drainage) $\left(15^{\circ} 24^{\prime} 37^{\prime \prime} \mathrm{S}, 57^{\circ} 42^{\prime} 20^{\prime \prime} \mathrm{W}\right)$, col. H.A. Britski et al., 04 Mar 2002; MZUSP 106061, 6 ex, Amazonas, Río Mavaca (Río Orinoco drainage), beach upstream from base-camp of Tapirapecó Expedition, col., R. Royero et al., 22 Mar 1988.

\section{ACKNOWLEDGMENTS}

We thank Alexandre Ribeiro who provided valuable suggestions during development of this paper. The manuscript benefitted greatly from reviews by C. DoNascimiento and T. Carvalho. We are grateful to Anderson Ferreira, Manoela Marinho, Osvaldo Oyakawa, Priscila Camelier, and Ricardon Zanon for their help in fieldwork. F.C.P.D. thanks Anderson Ferreira, Fabiano Antunes, Márcia Regina Russo and Adnara Ribeiro 
Gomide for administrative support at UFGD, MS and Bruna Barbosa (Prefeitura de Alcinópolis), Erciliomar Furquim Rocha (Prefeitura de Alcinópolis) and Sandro Menezes Silva (UFGD, MS) for logistical support in the field. We thank V. Reis and C. DoNascimiento for many discussions on trichomycterid evolution and systematics. V. Reis also made photographs used in figs. 1 and 4. Authors are partially funded for field activities to collect fish specimens by the Fundação de Amparo à Pesquisa do Estado de São Paulo - FAPESP, http://www.fapesp. br (F.C.P.D. \#2016/19075-9; M.P. \#2015/26804-4) and by the Conselho Nacional de Desenvolvimento Científico e Tecnológico - CNPq, http://www.cnpq.br (F.C.P.D. \#405643/2018-7; M.P. \#310688/2019-1).

\section{AUTHORS' CONTRIBUTIONS}

F.C.P.D., M.P.: Conceptualization, Methodology, Software, Data curation, Formal analysis, Writing - original draft, Visualization, Investigation. Writing - review \& editing. All authors actively participated in the discussion of the results, and reviewed and approved the final version of the paper. Authors declare no conflict of interest related to this paper.

\section{REFERENCES}

Albert, J.S. \& Reis, R.E. 2011. Introduction to neotropical freshwaters. In: Albert, J.S. \& Reis, R.E. (Eds.). Historical biogeography of Neotropical freshwater fishes. Los Angeles, University of California Press. p. 3-19.

Albert, J.S.; Tagliacollo, V.A. \& Dagosta, F. 2020. Diversification of Neotropical freshwater fishes. Annual Review of Ecology, Evolution, and Systematics, 51(1): 27-53. D0I

Ali, S.S.; Yu, Y.; Pfosser, M. \& Wetchnig, W. 2012. Inferences of biogeographical histories within subfamily Hyadnthoideae using S-DIVA and Bayesian binary MCMC analysis implemented in RASP (Reconstruct Ancestral State in Phylogenies). Annals of Botany, 109(1): 95-107. DOI

Assine, M.L. \& Soares, P.C. 2004. Quaternary of the Pantanal, west-central Brazil. Quaternary International, 114: 23-34. D0I

Baskin, J.N. 1973. Structure and relationships of the Trichomycteridae. Doctoral Thesis. City University of New York, New York.

Cardoso, A. 2008. Filogenia da família Aspredinidae Adams, 1854 e revisão taxonômica de Bunocephalinae Eigenmann \& Eigenmann, 1888 (Teleostei: Siluriformes: Aspredinidae). Doctoral Thesis. Pontifícia Universidade Católica do Rio Grande do Sul, Porto Alegre.

Carvalho, T.P. Arce-H., Mariangeles; Reis, R.E. \& Sabaj, M.H. 2018. Molecular phylogeny of Banjo catfishes (Ostaryophisi: Siluriformes: Aspredinidae): A continental radiation in South American freshwaters. Molecular Phylogenetics and Evolution, 127: 459-467. DOI

Carvalho, T.P.; Carsoso, A.R.; Friel, J.P. \& Reis, R.E. 2015. Two new species of the banjo catfish Bunocephalus Kner (Siluriformes: Aspredinidae) from the upper and middle rio São Francisco basins, Brazil. Neotropical Ichthyology, 13(3): 499-512. DOI

Carvalho, T.P.; Lundberg, J.G.; Baskin, J.N.; Friel, J.P. \& Reis, R.E. 2016. A new species of the blind and miniature genus Micromyzon Friel and Lundberg, 1996 (Silurifomes: Aspredinidae) from the Orinoco River:Describing catfish diversity using high-resolution computed tomography. Proceedings of the Academy of Natural Sciences of Philadelphia, 165(1): 37-53. D0I
Carvalho, T.P.; Reis, R.E. \& Friel, J.P. 2017. A new species of Hoplomyzon (Siluriformes:Aspredinidae) from Maracaibo Basin,Venezuela:Osteological description using high-resolution computed microtomography of a miniature species. Neotropical Ichthyology, 15(1): 1-16. DOI

Chuctaya, J.; Encalada, A.C.; Barragán, K.S.; Torres, M.L.; Rojas, K.E; OchoaHerrera, V. \& Carvalho, T.P. 2020. New Ecuadorian records of the eyeless banjo catfish Micromyzon akamai (Siluriformes: Aspredinidae) expand the species range and reveal intraspecific morphological variation. Journal of Fish Biology, Short communication. D01

Dagosta, F.C.P. 2021. Ernstichthys ctscan Siluriformes Aspredinidae. Harvard Dataverse Online repository. [dataset]. Available: http://doi. org/10.7910/DVN/XCXEM8. Access: 11/04/2021.

Dagosta, F.C.P. \& de Pinna, M. 2017. Biogeography of Amazonian fishes: deconstructing river basins as biogeographic units. Neotropical Ichthyology, 15(3): 1-24. DOI

Dagosta, F.C.P. \& de Pinna, M. 2018. A history of the biogeography of Amazonian fishes. Neotropical Ichthyology, 16(3): 1-19. D0I

Dagosta, F.C.P. \& de Pinna, M. 2019. The fishes of the Amazon: distribution and biogeographical patterns, with a comprehensive list of species. Bulletin of the American Museum of Natural History, 431(13): 1-163.

Dagosta, F.C.P.; de Pinna, M.; Peres, C.A. \& Tagliacollo, V.A. 2020. Existing protected areas provide a poor safety-net for threatened Amazonian fish species. Aquatic Conservation: Marine and Freshwater Ecosystems (special issue), 1-23. DOI

Dagosta, F.C.P.; Marinho, M. \& Camelier, P. 2014. A new species of Hyphessobrycon Durbin (Characiformes: Characidae) from the middle rio São Francisco and upper and middle rio Tocantins basins, Brazil, with comments on its biogeographic history. Neotropical Ichthyology, 12(2): 365-375. D0I

Datovo, A. \& Bockmann, F.A. 2010. Dorsolateral head muscles of the catfish families Nematogenyidae and Trichomycteridae (Siluriformes: Loricarioidei): comparative anatomy and phylogenetic analysis. Neotropical Ichthyology, 8(1): 193-246. D01

DoNascimiento, C. 2012. Sistemática y relaciones filogenéticas de la subfamilia de bagres parásitos Stegophilinae (Siluriformes, Trichomycteridae). Doctoral Thesis. Universidad Central de Venezuela, Caracas.

DoNascimiento, C. 2015. Morphological evidence for the monophyly of the subfamily of parasitic catfishes Stegophilinae (Siluriformes, Trichomycteridae) and phylogenetic diagnoses of its genera. 103(4): 933-960. D0I

Fernández-Yépez, A. 1953. Algunas notas sobre los peces Asprediformes con descripción de Ernstichthys anduzei, nuevo e interesante bunocephalido. Novedades Cientificas, Contribuciones Ocasionales del Museo de Historia Natural La Salle, Serie Zoológica, 11: 1-6.

Ferreira, K.M.; Faria, É.; Ribeiro, A.C.; Santana, J.C.0.; Quagio-Grassioto, I. \& Menezes, N.A. 2018. Gephyrocharax machadoi, a new species of Stevardiinae (Characiformes: Characidae) from the Rio Paraguai basin, central Brazil. Zootaxa, 4415(1): 161-172.

Friel, J.P. 1994. A phylogenetic study of the Neotropical banjo catfishes (Teleostei: Siluriformes: Aspredinidae). Doctoral Thesis. Duke University, Durham.

Friel, J.P. \& Lundberg, J.G. 1996. Micromyzon akamai, gen. et sp. nov., a small and eyeless banjo catfish (Siluriformes: Aspredinidae) from the River Channels of the lower Amazon basin. Copeia, 1996(3): 641-648.

Galdino, S.; Marinho, M. de A. \& Silva, J. dos S.V. da. 2013. Classification of pasture degradation levels in terms of hydric erosion risk in quartzipsamments areas at alto Taquari watershed (MS/MT, Brazil). Geografia, 95-107.

Giltay, L. 1935. Notes ichthyologiques. X. Description d'une espèce nouvelle de Trichomycteridae. Bulletin du Musée Royal d'Histoire Naturelle de Belgique, 11(27): 1-3. 
International Union for Conservation of Nature and Natural Resources (IUCN). 2020. The IUCN Red List of Threatened Species Version 2020-3., The IUCN Red List of Threatened Species Version 2020-3.

Jarduli, L.R.; Claro-García, A. \& Shibatta, 0.A. 2014. Ichthyofauna of the rio Araguaia basin, states of Mato Grosso and Goiás, Brazil. Check List, 10(3): 483-515. D0I

Kelley, W.E. \& Atz, J.W. 1964. A pygidiid catfish that can suck blood from goldfish. Copeia, 1964(4): 702-704.

Latrubesse, E.M.; Arima, E.; Ferreira, M.E.; Nogueira, S.H.; Wittmann, F.; Dias, M.S.; Dagosta, F.C.P. \& Bayer, M. 2019. Fostering water resource governance and conservation in the Brazilian Cerrado biome. Conservation Science and Practice, 1(9): 1-8. DOI

Lima, F.C.T. 2017. A revision of the Cis-Andean species of the genus Brycon Müller \& Troschel (Characiformes: Characidae). Zootaxa, 4222: 1-189.

Lima, F.C.T. \& Ribeiro, A.C. 2011. Continental-scale tectonic controls of biogeography and ecology. In: Albert, J.S. \& Reis, R.E. (Eds.). Historical biogeography of Neotropical freshwater fishes. Los Angeles, University of California Press. p. 145-164.

Lima, F.C.T.; Britski, H.A. \& Machado, F.A. 2007. A new Moenkhausia (Characiformes: Characidae) from central Brazil, with comments on the area relationship between the upper rio Tapajós and upper rio Paraguai systems. Aqua: journal of ichthyology and aquatic biology, 13: 45-54.

Lopes, D.A.; Taveira, T.T.M.; Severo-Neto, F. \& Carvalho, F.R. 2020. First record of Jupiaba acanthogaster (Eigenmann, 1911) (ostariophysi, characidae) in the upper Paraná river basin, Brazil. Check List, 16(4): 889-893. D0I

Lucena, C.A.; Calegari, B.B.; Pereira, E.H.L. \& Dellagrave, E. 2013. 0 uso de óleo de cravo na eutanásia de peixes. Boletim Sociedade Brasileira de Ictiologia, 105: 20-24.

Lujan, N.K. \& Conway, K.W. 2015. Life in the fast lane: A review of rheophily in freshwater fishes. In: Riesch, R.; Tobler, M. \& Plath, M. (Eds.). Extremophile Fishes. Cham, Springer International Publishing. p. 107-136.

Maddison, W.P. \& Maddison, D.R. 2019. Mesquite: a modular system for evolutionary analysis. Available: http://www.mesquiteproject.org.

Morrone, J.J. 1997. Biogeografía cladística: Conceptos básicos. Arbor, 158(623-624): 373-388.

Morrone, J.J. 2009. Evolutionary biogeography: an integrative approach with case studies. New York, Columbia University Press.

Myers, G.S. 1942. Studies on South American fresh-water fishes. I. Stanford Ichthyological Bulletin, 2(4): 89-114.

Ochoa, L.E.; Roxo, F.F.; DoNascimiento, C.; Sabaj, M.H.; Datovo, A.; Alfaro, M. \& Oliveira, C. 2017. Multilocus analysis of the catfish family Trichomycteridae (Teleostei: 0stariophysi: Siluriformes) supporting a monophyletic Trichomycterinae, Molecular Phylogenetics and Evolution, 115: 71-81. D01

Ohara, W.M. \& Zuanon, J. 2013. Aspredinidae. In: Queiroz, L.J. et al. (Eds.). Peixes do rio Madeira. São Paulo, Dialeto Latin Americano Documentary. p. 108-141.

Paixão, A. de C. \& Toledo-Piza, M. 2009. Systematics of Lamontichthys Miranda-Ribeiro (Siluriformes: Loricariidae), with the description of two new species. Neotropical Ichthyology, 7(4): 519-568. D01

Paranhos-Filho, A.C.; Nummer, A.R.; Albrez, E.A.; Ribeiro, A. \& Machado, R. 2013. A study of structural lineaments in Pantanal (Brazil) using remote sensing data. Anais da Academia Brasileira de Ciências, 85(3): 913-922.

de Pinna, M.C.C. 1996. A phylogenetic analysis of the Asian catfish families Sisoridae, Akysidae and Amblycipitidae, with a hypothesis on the relationships of the neotropical Aspredinidae (Teleostei, 0stariophysi). Fieldiana, Zoology, 84: 1-83.

de Pinna, M.C.C. 1998. Phylogenetic relationships of Neotropical Siluriformes: historical overview and synthesis of hypotesis. In: Malabarba, L.R. et al. (Eds.). Phylogeny and Classification of Neotropical Fishes. Porto Alegre, Edipucrs. p. 279-330. de Pinna, M.C.C. \& Ng, H.H. 2004. The second ural centrum in Siluriformes and its implication for the monophyly of superfamily Sisoroidea (Teleostei, Ostariophysi). American Museum Novitates, 3437(1): 1-23. D0I

de Pinna, M.C.C.; Reis, V.J.C. \& Britski, H.A. 2020. A new species of Trichogenes (Siluriformes, Trichomycteridae), with a discussion on the homologies of the anterior orbital bones in trichomycterids and other loricarioids. American Museum Novitates, 3951: 1-27.

Reis, V.J.C. \& de Pinna, M. 2019. The type specimens of Trichomycterus alternatus (Eigenmann, 1917) and Trichomycterus zonatus (Eigenmann, 1918), with elements for future revisionary work (Teleostei: Siluriformes: Trichomycteridae). Zootaxa, 4585(1): 100-120. DOI

Ribeiro, A.C.; Jacob, R.M.; Silva, R.R.S.R.; Lima, F.C.T.; Ferreira, D.C.; Ferreira, K.M.; Mariguela, T.C.; Pereira, L.H.G. \& Oliveira, C. 2013. Distributions and phylogeographic data of rheophilic freshwater fishes provide evidences on the geographic extension of a central-brazilian amazonian palaeoplateau in the area of the present day Pantanal Wetland. Neotropical Ichthyology, 11(2): 319-326.

Sabaj, M.H. 2020. Codes for natural history collections in ichthyology and herpetology. (3): 593-669. DOI

Schaefer, S.A. 1997. The Neotropical cascudinhos: Systematics and biogeography of the Otocinclus catfishes (Siluriformes: Loricariidae). Proceedings of the Academy of Natural Sciences of Philadelphia, 158: 1-120.

Silfvergrip, A.M.C. 1996. A systematic revision of the Neotropical catfish genus Rhamdia (Teleostei, Pimelodidae). Doctoral Thesis. Stockholm.

Slobodian, V. 2017. Taxonomic revision of Pimelodella Eigenmann \& Eigenmann, 1888 (Siluriformes: Heptapteridae): an integrative proposal to delimit species using a multidisciplinary strategy. Doctoral Thesis. Universidade de São Paulo, São Paulo.

Soriano, B.M.A.; Clarke, R.T. \& Galdino, S. 2001. Evolução da erosividade das chuvas na bacia do alto Taquari. Boletim de Pesquisa, Embrapa Pantanal, 25: 18.

Spotte, S. 2002. Candiru - Life and Legend of the Bloodsucking Catfishes. Berkeley, Creative Arts Book Company.

Stewart, D. 1985. A review of the South American catfish tribe Hoplomyzontini (Pisces, Aspredinidae), with descriptions of new species from Ecuador. Fieldiana Zoology, 25: 1-19.

Taphorn, D.C. \& Marrero, C. 1990. Hoplomyzon sexpapilostoma, a new species of Venezuelan catfish (Pisces: Aspredinidae), with comments on the Hoplomyzontini. Fieldiana Zoology, 61: 1-9.

Taylor, W.R. \& Van Dyke, G.C. 1985. Revised procedure for staining and clearing small fishes and other vertebrates for bone and cartilage study. Cybium, 2: 107-119.

Vari, R. 1988. The Curimatidae, a lowland neotropical fish family (Pisces: Characiformes); distribution, endemism, and phylogenetic biogeography. In: Heyer, W.R. \& Vanzolini, P.E. (Eds.). Proceedings of a workshop on Neotropical distribution patterns. Rio de Janeiro, Academia Brasileira de Ciências. p.343-377.

Yu, Y.; Harris, A.J. \& He, X. 2010. S-DIVA (Statistical Dispersal-Vicariance Analysis): A tool for inferring biogeographic histories. Molecular Phylogenetics and Evolution, 56(2): 848-850. DOI

Yu, Y.; Harris, J.J.; Blair, C. \& He, X. 2015. RASP (Reconstruct Ancestral State in Phylogenies): A tool for historical biogeography. Molecular Phylogenetics and Evolution, 87: 46-49. DOI

Zuanon, J. \& Sazima, I. 2004. Vampire catfishes seek the aorta, not the jugular: candirus of the genus Vandellia (Trichomycteridae) feed on major gill arteries of host fishes. Aqua, Journal of Ichthyology and Aquatic Biology, 8: 31-36.

Zuanon, J. \& Sazima, I. 2005. Free meals on long-distance cruisers: the vampire fish rides giant catfishes in the Amazon. Biota Neotropica, 5: 109-114. D0l 